\title{
Black Women's suffrage, the Nineteenth Amendment, and the Duality of a Movement
}

Danielle M. Conway

Penn State Dickinson Law, dzc5647@psu.edu

Follow this and additional works at: https://ideas.dickinsonlaw.psu.edu/fac-works

Part of the Election Law Commons, Fourteenth Amendment Commons, Law and Gender Commons, Law and Race Commons, and the Legal History Commons

\section{Recommended Citation}

Danielle M. Conway, Black Women's suffrage, the Nineteenth Amendment, and the Duality of a Movement (2021).

This Article is brought to you for free and open access by the Faculty Scholarship at Dickinson Law IDEAS. It has been accepted for inclusion in Faculty Scholarly Works by an authorized administrator of Dickinson Law IDEAS. For more information, please contact lja10@psu.edu. 


\title{
AlabAMA Civil Rights \& CIVIL
}

\section{LIBERTIES LAW REVIEW}

VOLUME 13.1

2021

\section{Black Women's Suffrage, the Nineteenth Amendment, AND THE DUALITY OF A MOVEMENT}

\author{
Danielle M. Conway*
}

\begin{abstract}
* Dean and Donald J. Farage Professor of Law, Penn State Dickinson Law, and cocurator of the AALS Law Deans Antiracist Clearinghouse Project. For research assistance on this article, I thank Associate Dean for Library and Information Technology Laura Ax-Fultz and the entire Penn State Dickinson Law Library faculty and professional staff and Penn State Dickinson Law 3L Lance Sacknoff. For feedback on the first draft, I thank the law students enrolled in my course, titled "Women's Suffrage, the Nineteenth Amendment, and the Duality of a Movement," specifically: Jessica DeLong, Kendra Eden, Danny Gray, John Greiner, Jackie Gross, Meagan Hopkins, Deborah Osborn, Tarig Shoush, and Jacqueline Stryker. For getting my course up and running, I thank Associate Dean for Academic Affairs Amy Gaudion and Registrar Pamela Knowlton. For inspiration and motivation, I thank Emmanuel Quainoo, Emmanuel Quainoo III, Gwendolyn Conway, Professor Melissa Murray, Professor Emerita Susan Hippensteele, Professor Martha S. Jones, Professor Mireille Rebeiz, Professor Stacey Suver, Professor Trina Jones, Dean Angela Onwuachi-Willig, the entire Penn State Dickinson Law Community, and all of the planners and participants of the Lutie A. Lytle Black Women Faculty Writing Workshop and Conference.
\end{abstract}


America is at an unprecedented time with self-determination for Black women. This phase of the movement is reverberating throughout this nation and around the world. ${ }^{1}$ There is no confusion for those who identify as Black women that this movement is perpetual, dating back to the enslavement of Black people in America by act and by law. ${ }^{2}$ One need only look to the intersecting crises of 2020 to discern the reality of Black women's - and by extension the Black community and by further extension individuals and groups marginalized, subordinated, and oppressed by white patriarchy - perpetual struggle for civil and human rights.

To appreciate the genealogy of this perpetual struggle for civil and human rights, it is instructive to look back on the 100th Anniversary of the Nineteenth Amendment and to be immersed in the stories and the legacies of Black women suffragists to gain insights about modern contestations against limiting the franchise. In the forming of this nation, Black women were intentionally excluded and erased from conceptions of humanity. ${ }^{3}$ This exclusion and erasure of Black women's voices and contributions from the annals of social, political, civil, and economic movements throughout history, such as abolitionist and women's suffrage movements, tarnish the legitimacy of our democratic institutions, our laws, and our collective progress toward equality.

This article centers Black women's lived experiences in the struggle for universal suffrage while also leading and supporting their communities in the fight against racial inequality and oppression. By making the sojourn through history using the lens of Black women, an opening is created to understand the perpetuation of racial injustice, subordination, and oppression through the practices of withholding citizenship and the manifestation thereof - the franchise. It also offers a window into the expertise and resilience of Black women in building and maintaining relationships, alliances, and coalitions to press for the larger vision of universal suffrage, even when their putative partners choose self-interest over the collective. The purpose of highlighting the duality of the movement is to contribute

1. See Black Women's Roundtable, Black Women in the U.S. 2021: Priorities, Policy and Power, NAT'L COALITION ON BLACK CIVIC PARTICIPATION 6, https://www.ncbcp.org/programs/bwr/BWR-2021-Report.pdf.

2. Mary Ellison, Resistance to Oppression: Black Women's Response to Slavery in the United States, 4 SLAVERY \& ABOLITION 56, 56 (1983).

3. Kimberly C. Harper, The Ethos of Black Motherhood in America: Only White Women Get PREgnant 23-24 (2020). 
to the literature that seeks to reveal how Black women and their lived experiences with racism, subordination, and oppression during the women's suffrage movement up through and after the ratification of the Nineteenth Amendment can inform today's efforts at successful coalition-building to support modern movements resisting and contesting injustice and inequality.

\section{TABle OF CONTENTS}

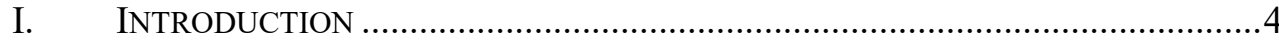

II. ENTERING THE WOMEN'S SUFFRAGE DISCUSSION ......................................

III. The DuAlity of Human HiERARCHY AND THE HyPOCRISY OF THE COEXISTENCE OF LIBERTY AND SLAVERY IN AN ABRIDGED History OF

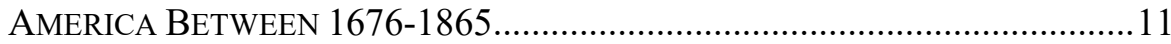

A. An Analytic Framework to Address the Duality Theme .......................11

B. Highlighting Dualities Through the Telling of an Abridged History

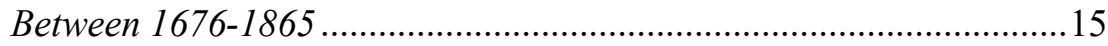

IV. THE Reconstruction AMENDMENTS AND THE DUALITY OF THE

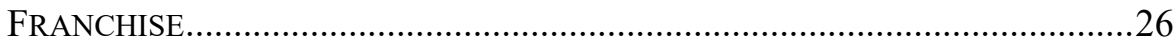

A. The Thirteen Amendment ....................................................................27

B. The Fourteenth Amendment …...............................................................36

C. The Fifteenth Amendment ...................................................................43

V. INTEREST CONVERGENCE, INTEREST DiVERGENCE, AND THE DUALITY OF

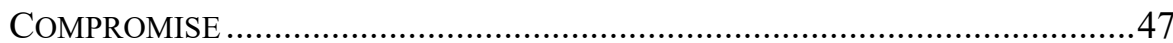

A. Interest Convergence/Divergence ......................................................48

i. Universal Humanists........................................................................48

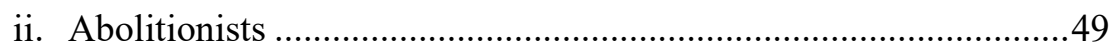

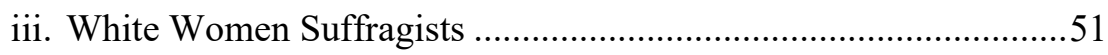

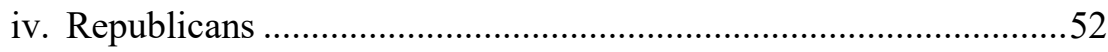

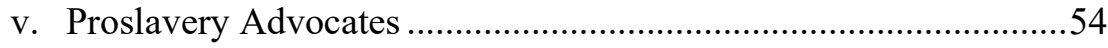

B. The Social and Political Impact of Internecine Compromise................56 
VI. THE EXClusivity IN THE LONG JOURNEY TO RATIFICATION OF THE NinETEENTH AMENDMENT: White WOMEN LEAVE BLACK WOMEN BEHIND

VII. Black Women as Collective AND CoAlition Partners AND Their PERPETUAL COMMitMENT to ACHIEVING Universal SufFRAGE. .75

VIII. CONCLUSION .82

\section{INTRODUCTION}

America is at an unprecedented time with self-determination for Black women. This phase of the movement is reverberating throughout this nation and around the world. ${ }^{4}$ There is no confusion for those who identify as Black women that this movement is perpetual, dating back to the enslavement of Black people in America by act and by law. ${ }^{5}$ One need only look to the intersecting crises of 2020 to discern the reality of Black women's - and by extension the Black community and by further extension individuals and groups marginalized and otherized by white patriarchy_-perpetual struggle for civil and human rights.

The intersecting crises of a global pandemic, which is disproportionately impacting Black and brown people; ${ }^{6}$ a full-throated social movement demanding racial equality following 2020's cascade of murders of, among others, Ahmaud Arbery, Breonna Taylor, and George Floyd; ${ }^{7}$ a presidential election in which voter

4. See Black Women's Roundtable, supra note 1.

5. Ellison, supra note 2.

6. Greg Johnson, COVID-19's Assault on Black and Brown Communities, U. PA: PENN TODAY (May 26, 2020), https://penntoday.upenn.edu/news/covid-19s-assault-blackand-brown-communities.

7. See Larry Buchanan et al., Black Lives Matter May Be the Largest Movement in U.S. History, N.Y. TIMES (July 3, 2020), https://www.nytimes.com/interactive/2020/07/03/us/george-floyd-protests-crowdsize.html; See Richard Fausset, Before Breonna Taylor and George Floyd, there was 
suppression was on full display, ${ }^{8}$ and a then-sitting president's apocryphal untruths regarding the election process, ${ }^{9}$ and the insurrection of January 6, 2021, have revealed the fault lines of American democracy, the maladies of structural racism and oppression, and the chasms between our lived experiences. ${ }^{10}$

Yet with these crises and their prevalence in perpetuity, the genealogy of Black women has been to engage the myriad struggles for civil and human rights and to contest the status quo of patriarchy, racism, and oppression through adherence to the disciplines of coalition-building and collective activism. One example of this engagement and activism is the documented, decades-long sojourn of Stacey Abrams to achieve universal suffrage through her service in the Georgia House of Representatives - seven as minority leader — to becoming the Democratic nominee for governor of Georgia in 2017 , followed by her snatching victory out of the jaws of the gubernatorial defeat in 2018 by turning the State of Georgia purple in the 2020 presidential election through her leadership of Fair Fight. ${ }^{11}$

Against the backdrop of a global pandemic, the killings of Black and brown people, state-supported violence against Black Lives Matter protesters seven months before the January 6 insurrectionists stormed the U.S. Capitol, ${ }^{12}$ and a long-pastdue awakening of many Americans to the fact that our nation is being hollowed out

Ahmaud Arbery, N.Y. Times (Feb. 28, 2021), https://www.nytimes.com/2021/02/28/us/ahmaud-arbery-anniversary.html.

8. William Wilder, Voter Suppression in 2020, BRENNAN CTR. FOR JUST. (Aug. 20, 2021), https://www.brennancenter.org/sites/default/files/202108/2021_08_Racial_Voter_Suppression_2020.pdf.

9. Zachary Wolf, The 5 Key Elements of Trump's Big Lie and How It Came to Be, CNN (May 19, 2021, 7:17 PM), https://www.cnn.com/2021/05/19/politics/donald-trumpbig-lie-explainer/index.html.

10. Michael Waldman, Trump's Big Lie Led to Insurrection, BRENNAN CTR. FOR JUST. (Jan. 12, 2021), https://www.brennancenter.org/our-work/analysis-opinion/trumpsbig-lie-led-insurrection.

11. See Stacey Abrams, Our Time Is Now: Power, Purpose, AND the Fight For a Fair AMERICA 11-16 (2020); see also STACEY ABRAMS, LEAD From THE OUTSIDE: How TO BuILD Your Future AND MAKe REAL CHANGE xii-xvii (2018).

12. Brakkton Booker, Tear Gas Fired on Protestors Again During Overnight Protests in Portland, NPR (July 27, 2020, 2:27 PM), https://www.npr.org/sections/live-updatesprotests-for-racial-justice/2020/07/27/895713277/tear-gas-fired-on-protesters-againduring-overnight-protests-in-portland. 
by the festering plague of systemic racism and inequities, ${ }^{13}$ Americans witnessed a symbol of the promise of democracy. In the perfect storm of these crises, record numbers of Americans participated in and bore witness to a Black and Indian woman accepting the Democratic Party nomination for Vice President of the United States. ${ }^{14}$ Then-Senator and now Vice President Kamala Harris is seen as a harbinger of universal suffrage, and the prophetic redeemer of the rule of law.

Vice President Kamala Harris's nomination acceptance speech coincided almost to the day-August 18, 2020 - with the marking of the 100th Anniversary of the Nineteenth Amendment. ${ }^{15}$ Accordingly, there is no more appropriate time to reflect on the history of Black women's justifiable resistance to those external to and in opposition with the franchise reformation movement - the capitalist, racist, and patriarchal individuals and institutions - and those internal to the strugglewhite, classist, racist, feminist leaders and advocates. These oppositional actors trade the liberty of an entire race of people for the guarantee of freedom for some and the protection of property for the white elite, as well as trade solidarity in

13. See U.N. High Comm'r for Hum. Rts., Promotion and Protection of the Human Rights and Fundamental Freedoms of Africans and of People of African Descent Against Excessive Use of Force and Other Human Rights Violations by Law Enforcement Officers, U.N. Doc. A/HRC/47/53 (June 28, 2021) ("[T] he concept of systemic racism against Africans and people of African descent, including as it relates to structural and institutional racism, is understood to be the operation of a complex, interrelated system of laws, policies, practices, and attitudes in State institutions, the private sector and societal structures that, combined, result in direct or indirect, intentional or unintentional, de jure or de facto discrimination, distinction, exclusion, restriction or preference on the basis of race, colour, descent or national or ethnic origin. Systemic racism often manifests itself in pervasive racial stereotypes, prejudice and bias and is frequently rooted in histories and legacies of enslavement, the transatlantic trade in enslaved Africans and colonialism.").

14. James M. Lindsay, The 2020 Election by the Numbers, COUNCIL ON ForEIGN Relations: THE WATER's EdGE (Dec. 15, 2020, 5:00 PM), https://www.cfr.org/blog/2020-election-numbers; See Li Zhou, Kamala Harris Officially Accepts the Democratic Vice Presidential Nomination and Makes History, VOX (Aug. 19, 2020 11:15 PM), https://www.vox.com/2020/8/19/21369433/kamalaharris-vice-presidential-speech-democratic-national-convention.

15. Kamala Harris' Address to 2020 Democratic National Convention, NPR (Aug. 19, 2020, 11:45 PM), https://www.npr.org/2020/08/19/904071636/watch-kamala-harrisaddress-to-2020-democratic-national-convention. 
universal freedom and suffrage for expediency, all of which has contributed to the persistent and pervasive inequity, inequality, and injustice that persists in this nation and prevents it from realizing the power and the promise of democratic ideals governed by the rule of law. ${ }^{16}$

The reawakening of our collective national consciousness through George Floyd's murder by police impunity and the prominence of the Black Lives Matter movement gives our nation another opportunity to acknowledge and grapple with its original evil sin. America has yet another moment to recognize and deal with the intentional erection of the social construct of race and racism that scaffolds the current system of white hierarchy and dominance. But crucially, it also has the chance to remonstrate against the debilitating practice of institutional and overt racism that has proved time and again detrimental to our collective humanity.

The historic achievements of Vice President Kamala Harris and movement attorney Stacey Abrams, among so many other Black women, especially considering their coalition-building for the public good, deserve to be acknowledged and celebrated but, more importantly, must be reflected upon and replicated if this nation is to make strides in delivering on the promise of equality for all. Specifically, Harris and Abrams, standing on the shoulders of the Black women before them, represent both a symbol of the promise of American democracy and its unrealized potential.

As with two sides of the same coin, the Nineteenth Amendment has provided both positive and negative "know-how" to shape the ultimate equal justice movement currently unfolding in America. To be clear, the positive "know-how" predating the ratification of the Nineteenth Amendment included articulating principles of liberty and justice, abolitionism, the birth of feminism, coalitionbuilding, and the development of self-determined, political personhood. ${ }^{17}$ The negative "know-how" documented up to and after the Declaration of Independence included, but was not limited to, resumption of the slave trade and chattel slavery,

16. See Editorial Board, Incrementalism Has Failed to Protect Americans from the Violence of Racism, DENV. POST, https://www.denverpost.com/2020/06/05/editorialincrementalism-failed-police-force-violence-racism-george-floyd/ (last updated June 5, 2020, 3:30 PM).

17. Robyn Muncy, The Necessity of Other Social Movements to the Struggle for Woman Suffrage, NAT'L PARK SERV., https://www.nps.gov/articles/the-necessity-of-othersocial-movements-to-the-struggle-for-woman-suffrage.htm\#_edn2 (last visited Nov. 4, 2021). 
flawed conceptions of human hierarchy, artifice, gamesmanship, and perfidy in preferring self-interest over collective, principled interests, often referred to as the public good. ${ }^{18}$ This more complete history must become familiar, and it must be wrestled with if there is to be a redemptive reformation in service to the democratic ideal of a more perfect union that explicitly recognizes that "all people are created equal," and that all people, too, are deserving of life, liberty, and the pursuit of happiness. ${ }^{19}$

Part II centers the voices of women, generally, and Black women, specifically. The section presents the perspectives of Black women and their relationships to democracy, citizenship, and the rule of law. Part III presents a discrete summary of the relevant history preceding the ratification of the Nineteenth Amendment, specifically touching on the American Revolutionary period, the antebellum period, the Civil War, and the Post-Civil War Reconstruction Act and Amendments. Part IV discusses the splintered movement to grant suffrage for Black men at the national level before achieving women's suffrage. It also examines the further splintering of the movement that effectively sought to continue the disenfranchisement of other groups, specifically Black women, all against a backdrop of Black Codes and Jim Crow.

Part $\mathrm{V}$ is an examination of interest convergences and interest divergences among five major constituencies in their political stances on slavery during the antebellum period, specifically in relation to the Fugitive Slave Act of 1850. This analysis shows some of the weaknesses in the politics of interest convergences and dualities of compromise which undercut the goals and objectives of the women's suffrage movement. Part VI frames the lessons learned from the splintered suffrage movements. It emphasizes that the fundamental indicia of citizenship is voting, an act of political and social self-determination, specifically for those who lack power or are among the most vulnerable in our society. Finally, Part VII makes the case that Black women are the symbol of universal suffrage in that their indefatigable

18. See Carrie Chapman Catt, Why the Southeastern States of the U.S. Refused Suffrage to Women - 1920, IOWA ST. U. (Dec. 31, 1969), https://awpc.cattcenter.iastate.edu/2019/01/16/why-the-southeastern-states-of-the-u-srefused-suffrage-to-women-1920/.

19. Joe Biden, Trump Erodes America's Foundation. This Fourth of July, I Pledge to Rebuild It, NBC (July 4, 2020, 6:15 AM), https://www.nbcnews.com/think/opinion/trump-erodes-america-s-foundation-fourthjuly-i-pledge-rebuild-ncna1232887. 
commitment to securing the vote for all citizens is a remarkable illustration of the promise of American democracy.

\section{ENTERING THE WOMEN's SUFFRAGE DISCUSSION}

History stands ready to share wisdom. The question is whether we, as a collective, are prepared to learn from it. Moreover, our nation - one conceived on fundamental freedoms for propertied white $m^{20}{ }^{20}$ has a complicated and unfortunate history to parse. Yet, this parsing must occur if America aspires to lead on humanism by acknowledging the power and promise of a United States Constitution so transformed by the Reconstruction Amendments and the Nineteenth Amendment.

Where, temporally, to begin this discussion is often as important as actually having it. ${ }^{21}$ Marking time is essential because discussions, deliberations, and decisions about the founding document and the Reconstruction Amendmentsconsidered the second founding-excluded Black people and women. Black women, whether enslaved or free, knew full well that their political, social, civil, and economic existence was inextricably linked to or directly tied to slavery as a legally-recognized institution. This damning connection existed on a spectrum between physical bondage and violence against personhood to exclusion from citizenship. With respect to the former, Black women knew that enslavers considered them nothing more than chattel, which also meant their children suffered the same fate. With respect to the latter, Black women's voices were generally discounted, muted, and ignored in the debates, deliberations, and decisions leading up to and following the ratification of the Nineteenth Amendment. The lived experiences of Black women resulted from political, social, civil, and economic structures scaffolded and sanctioned by law. Owing to this understanding, Black

20. Andrew Cohen, Constitution's Biggest Flaw? Protecting Slavery, U.C. BerkeleY: BERKLEY NEWS (Sept. 17, 2019), https://news.berkeley.edu/2019/09/17/constitutionsbiggest-flaw-protecting-slavery/; James Ely Jr., Property Rights in American History, HiLlSDALE C. 1, https://www.hillsdale.edu/wp-content/uploads/2016/02/FMF-2008Property-Rights-in-American-History.pdf (last visited Nov. 4, 2021).

21. Lisa Tetrault, The Myth of Seneca Falls: Memory and the Women's SUFFRAGE MOVEMENT, 1848-1898 6 (2014) (stating that "[a]lthough people are nearly universally driven to locate beginnings, we can never really know or fix them. 'Every event in history is a beginning, a middle, and an end."'). 
women knew that abolition of slavery and the law's recognition of their personhood were essential to their survival.

The knowledge that abolition and legal personhood were vital to their survival motivated Black women to resist and contest slavery. While not in the room where decisions were being made about their status, Black women used every avenue of escape, preached abolition and resistance, raised money for abolition societies, and used many tactics to protect their children. The Civil War, Emancipation, and the Reconstruction era provided a measure of hope for Black women to look to law to acknowledge their existence, their rights to protect their bodies and the bodies of their children, and their citizenship. But the laws that scaffolded and institutionalized slavery are the same laws that almost immediately curtailed the political, social, civil, and economic rights of Black people, including Black women.

From the inhumanity of genocide, slavery, and subordination to the injustices of Jim Crow, racism, and sexism, the law must account for its intimate relationship with the history of slavery and its vestiges. The integrity it takes to face and acknowledge complicity in "imperial and unnatural acts" 22 and the will to join the movement to dismantle the racist patriarchy from which it flows are the manifestations of service to the American ideals of equality and justice. This type of service is what is required of law and those who are called to it. Within the system of laws there must be a reckoning that requires a contextual reformation of the founding document and the Reconstruction Amendments of the second founding. Only through such a reckoning will there be an excavation of equality through investigation, analysis, interrogation, and dissemination of those voices left out of the structure of this society and its legal scaffolding. What will result is a contextdriven approach to defending democracy and promoting the rule of law, which was the promise of the second founding. ${ }^{23}$ Women's Suffrage illustrates the importance of this premise. Women's Suffrage is a most appropriate example because our nation has celebrated the 100th Anniversary of the ratification of the Nineteenth

22. Cheryl Clark, Foreword to AUdRE LORDE, SisTER OUTSIDER: ESSAYS AND SPEECHES 6 (Crossing Press Feminist Series) (Ten Speed Press 2013).

23. See Robert M. Jarvis et al., Contextual Thinking: Why Law Students (and Lawyers) Need to Know History, 42 WAYNE L. REV. 1603, 1604 (1996). 
Amendment ${ }^{24}$ which prohibits sex-based disenfranchisements, yet—-structurallysecures in women the right to vote. ${ }^{25}$

But Women's Suffrage and the ratification of the Nineteenth Amendment carry disturbing truths that those in service to the second founding, a multicultural democracy, and a more robust rule of law, cannot ignore. It is her story, with all of its facets, that must be told because it is critically important to an understanding of the how and the why of expansion of the voting franchise to white women in 1920, which simultaneously continued the exclusion of Black women and women of color from full enfranchisement. ${ }^{26}$ Because of the proximity of Black women, among other women of color, to the business end of both racism and sexism, ${ }^{27}$ their voices and lived experiences are the canaries in the coal mine for the future assaults on democracy and the rule of law. The experiences of Black women demonstrate why a heightened duty for lawyers is required to acknowledge the complicity of law and legal systems in scaffolding systemic racial inequality and intersectional injustice that were and remain the vestiges of slavery, Black Codes, the nadir, Jim Crow, and Jane Crow.

\section{THE DUALITY OF HUMAN HIERARCHY AND THE HYPOCRISY OF THE COEXISTENCE OF LIBERTY AND SLAVERY IN AN ABRIDGED HISTORY OF AMERICA BETWEEN 1676-1865}

\section{A. An Analytic Framework to Address the Duality Theme}

Telling her story by accounting for diverse voices is a narrative device that depends on challenging revisionist expressions of past events, resurrecting voices omitted from history, and highlighting new knowledge resulting from the inclusion

24. 2020 Women's Vote Centennial Initiative, https://www.2020centennial.org/ (last visited Oct. 26, 2021).

25. U.S. CONST. amend. XIX.

26. Bandana Purkayastha, From Suffrage to Substantive Human Rights: The Continuing Journey for Racially Marginalized Women, 42 W. NEW ENG. L. REV. 419, 421 (2020).

27. Patricia A. Broussard, Unbowed, Unbroken, and Unsung: The Unrecognized Contributions of African American Women in Social Movements, Politics, and the Maintenance of Democracy, 25 WM. \& MARY J. RACE GENDER \& SOC. JUST. 631, 631-32 (2019). 
of different perspectives. ${ }^{28}$ The lived experiences, theories, and writings of Frederick Douglass, Derrick Bell, and bell hooks have great utility for developing a framework to identify the existence of dualities as forces or kinds of actions that interfere with and discourage progress toward equality and universal suffrage. ${ }^{29}$ It is possible to build beyond the limiting nature of transactional coalitions by exposing dualities and interrogating them from the perspective of Black women who took part in abolitionist, women's suffrage, and universal rights movements. Doing so will deepen relationships that will advance equality movements and the organizing around them. The goals and strategies attendant with these deeper relationships are to achieve more than the incremental success of one-issue causes or the aims of only one group of beneficiaries. In exposing dualities within movements, it is instructive to look to the works of Frederick Douglass, Derrick Bell, and bell hooks to discern their impressions about sustaining movements for equality.

Frederick Douglass was the great exposer of human hypocrisy and the many dualities that fueled it. ${ }^{30}$ For example, his writings and oratory detailed slave society as "a place of jarring contrasts and brutal contradictions." 31 At the heart of Douglass's themes was the idea that slavery "attempted to crush all semblance of natural rights for its victims" and was nothing short of sanctioned piracy and tyranny that negatively impacted all of humanity. ${ }^{32}$ His was a direct and relentless assault on the institution of slavery and on those who benefitted from, supported, or willfully or unconsciously ignored America's slavocracy. He channeled his activism and organizing through joining many coalitions, including those committed to

28. John H. Bracey Et Al., African American Women and the Vote, 1837-1965 8 (Ann D. Gordon ed., 1997).

29. See Rhonda V. Magee Andrews, Racial Suffering as Human Suffering: An Existentially-Grounded Humanity Consciousness as a Guide to a Fourteenth Amendment Reborn, 13 TEMP. POL. \& CIV. RTS. L. REV. 891, 898 (2004).

30. Frederick Douglass, The Hypocrisy of American Slavery, History Place: GREAT SPEECHES COLLECTION (July 4, 1852), https://www.historyplace.com/speeches/douglass.htm.

31. David W. Blight, Frederick Douglass: Prophet of Freedom 20 (2018).

32. Id. at 26 . 
women's suffrage. ${ }^{33} \mathrm{He}$ invested his time and energy in relationship-based coalitions. He exhibited unwavering loyalty to his partners and their ultimate objectives, even when he needed to change strategies and tactics to match changed conditions on the ground. ${ }^{34}$

Derrick Bell, like Frederick Douglass, chose to perceive the world "as it is rather than how we might want it to be." ${ }^{, 35}$ Thus, identifying dualities undergirded his principle of interest convergence, which provides that " $[t]$ he interests of blacks in achieving racial equality will be accommodated only when it converges with the interests of whites." ${ }^{36}$ As such, any "remedy providing effective racial equality for blacks where the remedy sought threatens the superior societal status of . . whites" will not be authorized. ${ }^{37}$ Bell counseled Black people to be prepared for the backlash against black progress and recognize that black progress would only extend by the degree to which that progress operated to enforce racial hierarchy in the long run, thereby concluding the permanence of racism in America. ${ }^{38}$ Even with this sobering revelation about the permanence of racism, Bell continued to work with organizers and political organizations to pursue racial justice. ${ }^{39}$

Building on Douglass's exposition of human hypocrisy as contrary to natural rights and on Bell's theory of racial equality being metered by interest convergence, bell hooks makes extensive contributions to deploying the concept of duality by interrogating racialized metaphors that, first, expose white women's history with performances of sisterhood and solidarity along interest convergence

33. John W. Cromwell, Negro in American History: Men and WOMEn EMinent in THE EVOLUTION OF THE AMERICAN OF AFRICAN DESCENT 153 (1914).

34. Rachelle C. Prioleau, Combining Abolitionism and Women's Suffrage: The Agenda BuILding Process and Discursive Strategies of Frederick Douglass 99 (2000).

35. Derrick A. Bell, Jr., Comment, Brown v. Board of Education and the Interest Convergence Dilemma, 93 HARV. L. REV. 518, 523 (1980).

36. Id.

37. Id.

38. Michelle Alexander, Foreword to DerRick A. Bell, JR., FACES AT THE BotTOM OF THE Well: THE PeRMANENCE OF RACISM xvii-xviii (2018).

39. Charles R. Lawrence III, Doing "The James Brown” at Harvard: Professor Derrick Bell as Liberationist Teacher, 8 HARV. BLACKLETTER J. 263, 268-71 (1991). 
lines and, second, erases Black women's identities and experiences by promoting rhetorical narratives that make women synonymous with white women. ${ }^{40}$ By interrogating the race-sex metaphorical device used by white women during abolitionist, women's suffrage, and universal rights movements, the maintenance of the patriarchal power structure comes into sharper focus as the compromise necessary to retain the status quo of the negotiated white hierarchy. hooks did not give up on the collective feminist struggle, even though many white women turned their backs on feminist ideology once they achieved their desired ends. ${ }^{41}$ Instead, she continued to counsel that "change occurs only when there is action, movement, revolution." 42 Looking at the lived experiences of Black women in the Nineteenth Century, hooks informs us that Black women's "suffering, the harshness of her lot in a racist, sexist world, and her concern for the plight of others motivated her to join feminist struggle." 43 hooks reveals to us that Black women "did not allow the racism of white women's rights advocates or the sexism of [men, including Black men] to deter her from political involvement." 44 Further, she states that Black women "did not rely on any group to provide her with a blueprint for change. She was a maker of blueprints." 45

For the purposes of the ensuing discussion, the concept of duality means instances of opposition, which may at times be irreconcilable and at other times may be susceptible to reconciliation. In addition, dualities presuppose the capacity to reason, yet the absence of the will to follow such reasoning to its natural conclusion. The duality of a movement specifically references instances of opposition within and among the abolitionist and women's suffrage movements to address (or not) the interrelated objectives of both movements. The component parts of the duality of a movement framework, for purposes of this discussion, are the ultimate objective of the movement for universal suffrage being subjected to oppositional views along a

40. BELL HOOKS, AIN'T I A WOMAN: BLACK WOMEN AND FEMINISM 138-42 (1981) ("No other group in America has used black people as metaphors as extensively as white women involved in the women's movement.").

41. Id. at 192 .

42. Id. at 193.

43. Id.

44. Id.

45. $I d$. 
continuum that featured debate, disagreement, and decision-making about how, when, and whether to pursue the objective. Along the duality of a movement continuum, abolitionists and women's suffragists formed transactional coalitions that made them susceptible to dilutive, oppositional, and/or irreconcilable views. Dilutive and oppositional views led to outcomes and compromises that gave meaning to interest convergence. In contrast, irreconcilable dualities fueled a repugnance to and inconsistency with a moral belief system predicated on democratic ideals and the rule of law. Irreconcilable dualities in a movement for equality and universal suffrage are fatal from the outset, as there is no basis upon which to build and sustain coalitions to dismantle racial hierarchies, subordination, and oppression. ${ }^{46}$

Accordingly, using the concept of duality helps to sharpen the focus on when human hypocrisy contravenes natural rights, erodes coalition partnerships, and impedes the dismantling of racist ideas, hierarchies, and social structures. The myriad dualities that hampered America's formation and second founding, as illustrated by the contradictions of liberty and slavery, radical versus gradual positions on abolitionism, and the transactional coalitions in pursuit of the franchise, all provide a more nuanced framework for examining the history of the movement that led to the ratification of the Nineteenth Amendment. The dualities impacting various movements and reform work during the time leading up to the ratification of the Nineteenth Amendment must be interrogated to make visible important lessons for a Second Reconstruction. This Second Reconstruction is built on decades of social movement organizing for equality from Black Lives Matter and \#MeToo to \#SayHerName and \#SheWillRise.

\section{B. Highlighting Dualities Through the Telling of an Abridged History Between 1676-1865}

Between 1676 and 1776, American colonies were "reasonably independent of British authority." 47 The relationship dissolved when men of British ancestry in

46. Paul Gowder, The Rule of Law in the Real World 6 (2016).

47. Introduction to Centuries of Citizenship: A Constitutional Timeline, NaTIONAL CONSTITUTION CENTER, https://constitutioncenter.org/timeline/html/cw01.html (2006). 
the Americas embraced a new principle of government. ${ }^{48}$ Thomas Jefferson wrote that "Governments are instituted among men," sloughing off taxation without representation and any virtual representation of themselves by those in British parliament. ${ }^{49}$ At this point in history, landless white men were overwhelmingly not included as beneficiaries of this principle. ${ }^{50}$ Black people remained white people's property, and the products of the formers' labor meant continued and increasing prosperity for the latter enslavers. ${ }^{51}$

While rebelling against the British rule over America, white elites - the majority of whom claimed English ancestry-hypocritically adopted slave codes making slavery official throughout the American colonies. ${ }^{52}$ Essentially replicating and recreating British hierarchy in their image, American white men capriciously crowned themselves the new patriarch through the establishment of "voting [as] a privilege of the few, not a right of all., ${ }^{53}$

Rebuking Lords and a King, white elites rejected the apparent authority of British rule and, in its place, established republics and state constitutions leading to the eventual adoption of the United States Constitution that incorporated both direct and indirect provisions that dealt with slavery. ${ }^{54}$ White men reinforced their

48. H.T. Dickinson, The Failure of Conciliation: Britain and the American Colonies 17631783, 79 KYOTO ECON. REV. 2, 2 (2010).

49. THE DECLARATION OF INDEPENDENCE para. 2 (U.S. 1776).

50. LaJuana Davis, The Legal Implications of the Voting Rights Act Consent Decree on Jefferson County's Government, 40 CUMB. L. REV. 815, 820 (2009).

51. John P. KAMINSKI, Introduction to A NeCESSARy EVIL?: SlaVery AND the Debate OVER THE CONSTITUTION x (1st ed. 2016) (explaining while the First and Second Continental Congresses committed the colonies not to import or purchase slaves from Africa after December 1, 1774, this measure was undertaken to resume economic war against the British Parliament rather than to acknowledge the evils of slavery or the redemptive nature of emancipation.)

52. Id. at $1-2$.

53. Reva B. Siegel, The Nineteenth Amendment and the Democratization of the Family, 129 YALE L.J.F. 450, 456 (2020).

54. See Tetrault, supra note 21 , at $42-43$ (explaining the four specific provisions on slavery were (1) three-fifths of the slave population was to be considered in apportioning direct taxes and representation in the U.S. House of Representatives; (2) the foreign slave trade could not be prohibited before 1808 and a tax levied on imported 
enslavement of Black people using the law, the economy, the political process, geography, public opinion, and claims of national necessity - all in stark contrast to their commitment to liberty and justice for all. ${ }^{55}$ One byproduct of the enslavement of Black people was the elevation of white women to a new status in America's formulation of white hierarchy. ${ }^{56}$

From the first contact with the Americas to the Declaration of Independence and the ratification of the United States Constitution, America's white elite zealously guarded their liberty and property interests by ultimately reorganizing government on the one hand and condoning and sanctioning slavery and arbitrary hierarchy on the other. ${ }^{57}$ The Eighteenth-century ended with a new governing

slaves could not exceed ten dollars per slave; (3) runaway slaves had to be returned to their masters "on demand" and could not be emancipated; and (4) no amendments to the Constitution prohibiting the slave trade could be adopted before 1808. A partial list of constitutional provisions that indirectly affected slavery included: (1) authorizing Congress to call forth the militia to help suppress domestic insurrections (including slave uprisings); (2) prohibitions on both the federal and state governments from levying export duties, thereby guaranteeing that the products of a slave economy ... would not be taxed; (3) providing for the indirect election of the president through electors based on representation in Congress, which, because of the three-fifths clause, inflated the influence of the white Southern vote; (4) requiring a three-fourths approval of the states to adopt amendments to the Constitution, thus giving the South a veto power over all potential amendments; and (5) limiting the privileges and immunities clause to "citizens," thus denying the protections to slaves and in some cases to free Blacks.).

55. See generally William M. Carter Jr., Thirteenth Amendment and Constitutional Change, 38 N.Y.U. REV. L. \& SoC. CHANGE 583, 584 (2014) (explaining how "the surrounding infrastructure of customs, practices, and systemic forms of racial subordination . . . supported an ideology of white supremacy, which enabled the system of slavery to prosper and persist.").

56. See KAMINSKI supra note 51, at 153 (explaining that "[p]rior to slavery, patriarchal law decreed white women were lowly inferior beings, the subordinate group in society. The subjugation of black people allowed [white women] to vacate their despised position and assume the role of a superior." hooks argued that "even though white men institutionalized slavery, white women were its most immediate beneficiaries ... creat[ing] a new status for [her]. The only way that her new status could be maintained was through the constant assertion of her superiority over the black woman and man.").

57. JOHN HOPE Franklin \& EVElyn BroOKS HigGinbotham, From SLAVERy to FREEDOM: A HiSTORY OF AFRICAN AMERICANS 100, 102 (9th ed. 2011) (citing Shay's 
document in place - the United States Constitution. ${ }^{58}$ For white, propertied men, the United States Constitution embodied new ideas about government "by the people," with power divided between the states and the national government. ${ }^{59}$ In 1791, the United States Constitution was expanded by the Bill of Rights, the first ten amendments securing for individuals - white men-guarantees of personal liberties. ${ }^{60}$ Even though Congress abolished the African slave trade in $1808,{ }^{61}$ expansion into western territories took hold, and slavery extended with it. ${ }^{62}$ Ascriptive caste was embedded into the evolved definition of who was American, juxtaposing enslaved Black people as nothing more than chattel property. Even at the bottom of America's human hierarchy and in bondage, Black people used law, military service, moral suasion, protests, petitions, and resistance to mirror the political ideology that proved successful for white American elites during the Revolution. ${ }^{63}$

The Constitution permitted the Atlantic slave trade to continue until 1808, appeasing the interests of Southern states. ${ }^{64}$ It explicitly recognized, in law, the

Rebellion as the impetus for elite white men's pursuit of compromise with white small farmers and landless rural workers who demanded liberal and democratic land laws, moratoriums on debts, and general guarantees of human rights. The demand for democratization also reverberated through enslaved and abolitionist communities, who called for the destruction of property interests in human beings.).

58. Louis Henkin, Economic Rights Under the United States Constitution, 32 Colum. J. TRANSNAT'L L. 97, 105 (1994).

59. Roberta Sue Alexander, An Historical Perspective on the Constitution, 12 U. DAYTON L. REV. 321, 328 (1986).

60. Paula Rhodes, We the People and the Struggle for a New World: The Constitution of the United States of America and International Human Rights, 30 HOWARD L. J. 997, 1000 (1987).

61. KAMINSKI, supra note 51, at 239.

62. Kenneth M. Stampp, The Peculiar Institution, in Slavery as a CAUSE OF THE CIVIL WAR 79, 85 (Edwin C. Rozwenc ed., 1963).

63. Id. at 87.

64. Paul Finkelman, Slavery in the United States: Persons or Property? in The Legal UNDERSTANDING OF SLAVERY 105, 117-118 (2012). 
institution of slavery, which was supported by both Northern and Southern state delegates to the Constitutional Convention. ${ }^{65}$

It recognized the property interest in human beings with the inclusion of the Fugitive Slave Provision. ${ }^{66}$ The Constitution assuaged the Southern state delegates who vigorously argued for an electoral vote system that would allocate taxes and seats in Congress by counting enslaved Black people according to a three-fifths ratio to white people. ${ }^{67}$

It is this last point that connects the two issues: enfranchisement on the one hand and the duality of liberty and slavery on the other. While Black people made exhaustive attempts to expose this duality - in part by accessing self-help, and the legal system ${ }^{68}$ and, yes, being joined by some "sympathetic whites" 69 who were Quakers, theologians, politicians, and members of the bench and bar-the ratification of the U.S. Constitution unified, for all white people, the benefits of the guarantee of their version of liberty and freedom. ${ }^{70}$ This exclusive version of liberty and freedom prioritized the protection of white people's property interests in human beings over their putative founding principles.

Satisfied to continue the states' stalemate regarding slavery and the foreign slave trade, the first federal Congress rejected claims that Congress had the power to prohibit the importation of the enslaved or to emancipate or manumit them, as was urged by reenergized abolitionist societies. ${ }^{71}$ Although " $\left.t \mathrm{t}\right]$ he general attitude of Americans in the North and South toward slavery continued to drift apart," the

65. Id. at 117 .

66. See KAMINSKI, supra note 51, at 65.

67. Id. at $50-52$.

68. See Franklin \& HigGinbotham, supra note 57, at 87.

69. See, e.g., Amy Reynolds, Through the Eyes of the Abolitionists: Free Association and Anti-Slavery Expression, 11 COMM. L. \& POL'Y 449, 454 (2006) ("The eighteenth century was a significant marker for the American abolitionist movement because several prominent anti-slavery Quakers emerged and began to organize.").

70. See KAMINSKI, supra note 51, at 202-03.

71. Id. 
stalemate persisted. ${ }^{72}$ "By the end of the first federal Congress it was apparent that despite the strong opposition to the African slave trade, Congress would not act to ameliorate the terrible conditions endured by Africans in the slave trade, much less to abolish the trade." 73 In this duality and the stalemate born from an active stance to maintain the status quo, "Southerners found support from Northerners to postpone action indefinitely.",74

In addition to tacit agreement to further the status quo, another unifying theme became apparent. Americans from Northeast states, Mid-Atlantic states, and Southern states shared the belief that enslaved Black people were inferior to whites. ${ }^{75}$ This belief further solidified racist ideas that encouraged viewpoints along a relatively short spectrum. One perspective articulated that emancipation, if appropriate, should be accomplished gradually to provide "due process" in the form of compensation to slaveowners. ${ }^{76}$ Another perspective was that emancipation would relieve slaveowners because enslaved Black people "were generally thieves, idlers and squanderers of their masters' property." 77 Further along the spectrum was

72. Id. at 203. An example of this stalemate was the Fugitive Slave Act of 1793, which established a process for slaveowners to recover runaway enslaved Black people. The Act was difficult to enforce and, worse, it led to the indiscriminate kidnapping and enslavement of free Blacks. The 1807 Act prohibiting the foreign slave trade became law, but it was equally ineffective; Southern states did not enforce it, largely out of fear that the Act was the first step toward federal regulation of the domestic slave trade and would provide the pretext for universal emancipation.

73. Id.

74. Id. at 203.

75. See id. at 245 ("Jefferson and Madison, as well as many other slaveholders in the North and in the South, believed that blacks were inherently inferior to whites.").

76. Id. at 240; see also Marlene Daut, When Haiti Paid France for Freedom: The Greatest Heist in History, THE AFRICA REPORT (July 2, 2020, 5:13 PM), https://www.theafricareport.com/32162/when-haiti-paid-france-for-freedom-thegreatest-heist-in-history/ ("On April 17, 1825, the French king ... issued a decree stating France would recognize Haitian independence but only at the price of 150 million francs - or 10 times the amount the U.S. had paid for the Louisiana territory. The sum was meant to compensate the French colonists for their lost revenues from slavery.").

77. See KAMINSKI, supra note 51, at 232. 
the Southern perspective - that slavery was not even considered an evil. ${ }^{78}$ The final point along the spectrum was the perspective that abolitionism and emancipation were the greatest evils because they would lead to interracial warfare and carnage. ${ }^{79}$

During the antebellum period, in 1820, Congress reached an agreement on the Missouri Compromise, allowing existing states to choose their own course to either pursue or not pursue the continued enslavement of human beings. ${ }^{80}$ The limited goal of the congressional compromise was to slow the spread of slavery by setting the northern limit of slavery along the Missouri Compromise Line, except for Missouri, which entered the Union as a slave state. ${ }^{81}$

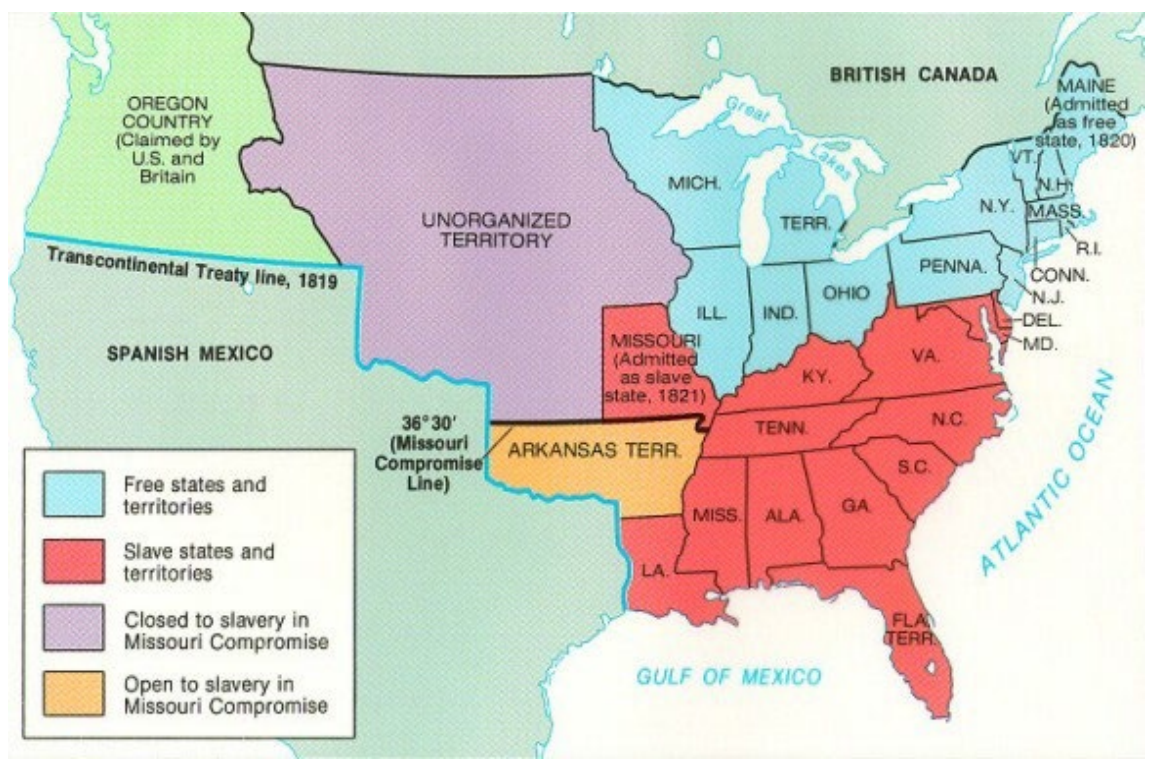

78. Id.

79. Id.

80. E.g., Faith Joseph Jackson, Dred Scott v. Sandford: A Prelude to the Civil War, 15 RICH. J.L. \& PUB. INT. 377, 381-382.

81. Id. at 382 .

82. Socks, Events Leading to the Civil War, TIMETOAST, https:/www.timetoast.com/timelines/events-leading-to-the-civil-war-dd279d1e-0bb847b3-9759-a6c56b422755 (last visited Nov. 18, 2021). 
In the 1820 s and 1830 s, America continued westward expansion, ${ }^{83}$ and American elite white men secured political power by extending the voting franchise to include all white men. ${ }^{84}$ In the upper southern states, the demand for labor and the concomitant success of cotton as a southern crop, increased the domestic market for enslaved Black people. ${ }^{85}$ The South was entrenched in slavery, while in the North, the institution of slavery was nearing its end. ${ }^{86}$ While the end of slavery in the North and the presence of putatively free Black people became common, the prevalence of anti-Black racism far from guaranteed their rights as freed people and citizens. Stated another way, even as freed or free-born, racism ensured that Black people continued to experience liminal existences, as full citizenship was always out of reach. ${ }^{87}$

During this period, the Missouri Question loomed large. Missouri, a slaveholding territory, "proposed a state constitution that mandated laws "to prevent free negroes and mulattoes from coming to and settling in the State...." 88 This proposed prohibition on in-migration raised a constitutional question about the privileges and immunities guarantee, leading ultimately to a question about jus soli-birthright citizenship. ${ }^{89}$ As with prior opportunities for watershed moments to

83. E.g., Andrew P. Morriss \& Craig Allen Nard, Institutional Choice \& Interest Groups in the Development of American Patent Law: 1790-1865, 19 SUP. CT. ECON. REV. 143, 193 (2011) ("The territorial expansion of the United States westward and the growth of population in the West is one of the great themes in nineteenth century American history.").

84. See Stanley L. Engerman \& Kenneth L. Sokoloff, Economic Development in THE AMERICAS SINCE 1500: ENDOWMENTS AND INSTITUTIONS 109 (2011).

85. See Domestic Slave Trade, EQuAL Just. InItIATIVE (July 1, 2014), https://eji.org/news/history-racial-injustice-domestic-slave-trade/.

86. Paul Finkelman, An Imperfect Union: Slavery, Federalism, and COMity 36 (2000).

87. Id. at 15,18 .

88. Martha S. Jones, Birthright Citizens: A History of Race and Rights in ANTEBELLUM AMERICA 27 (2018).

89. In Scott v. Sandford, 60 U.S. 393 (1857), the United States Supreme Court refused to recognize the grant of citizenship to Black people born within the geographic boundaries of the United States. The Fourteenth Amendment superseded the Scott 
embrace humanity and justice, Congress punted on the question and retreated to the familiar ground of compromise, allowing Missouri to bar free Black people from entering the jurisdiction. ${ }^{90}$ At the same time, enslaved Black people, free Black people, and First Peoples were being re-enslaved, disenfranchised, and subordinated, and sometimes were corralled and removed by violence, threat of violence, or intimidation perpetrated by white men. ${ }^{91}$ To consolidate even more power, white men rewrote state constitutions in the wake of the outcome in Missouri, stripping away whatever rights remained for free Black people and worsening conditions for enslaved Black people. ${ }^{92}$

Black people's status as enslaved chattel was a political act by the white patriarchy that shrouded the right to own another human being in concepts of American law and liberty. The status of "slave" was reinforced with dehumanizing tactics, including, but not limited to:

decision, and in United States v. Wong Kim Ark, 169 U.S. 649 (1898), the Supreme Court further clarified that the Fourteenth Amendment grants American citizenship to any individual born in the United States, regardless of the citizenship status of that individual's parents. For further definition of jus soli and the application of this doctrine to territories within the British Empire, see Inglis v. Trs. of Sailor's Snug Harbor, 28 U.S. 99 (1830). In Tuaua v. United States, 788 F.3d 300 (D.C. 2015), this expansive reading of jus soli in light of the Wong Kim Ark decision was discussed and rejected for individuals born in American Territories.

90. See JONES, supra note 88, at 28.

91. See generally id.

92. For example, the Missouri Constitution of 1820 states: "The general assembly shall have no power to pass laws; First, For the emancipation of slaves without the consent of their owners, or without paying them, before such emancipation, a full equivalent for such slaves so emancipated ... [and the general assembly] shall have power to pass laws ... [t]o prevent free negroes and mulattoes from coming to, and settling in, this state, under any pretext whatsoever[.]" MO. CONST. of 1820, art. III, § 26. Other states, such as South Carolina, amended their constitution in 1810 to extend suffrage to "[e]very free white man, of the age of twenty-one years[.]" S.C. CONST. of 1790, art. I, $\S 4$ (1810). South Carolina excluded even the possibility of a Black political representative: "No person shall be eligible to a seat in the house of representatives unless he is a free white man." Id. § 6. See also ALA. CONST. of 1819, art. III, § 4 ("No person shall be a representative unless he be a white man[.]"); TENN. CONST. of 1834, art. IV, $\S 1$ ("Every free white man of the age of twenty-one years . . . shall be entitled to vote for Members of the general Assembly."). 
- extending the rights of slaveowners to their property, especially in defending laws that continued chattel slavery by defining the status of a Black woman's children, regardless of the race of the biological father, as property; ${ }^{93}$

- criminalizing literacy of enslaved Black people; ${ }^{94}$

- erasure of names, status, and language, and promoting the assumption in abolitionist and emancipation circles that experiences of enslaved Black men were more important than those of Black women; ${ }^{95}$ and

- sexual exploitation of enslaved Black women who could not receive justice under law because no such crime "against property" existed to ensure or legally respond to her inviolability. ${ }^{96}$

Alongside these organized political actions to entrench slavery, racial science and bigotry became rampant. Craniology and Polygenesis were touted as

93. ANGela Y. DAVIS, WOMEn, RACE \& Class 7 (1981) (“[Because] slave women were classified as 'breeders' as opposed to 'mothers,' their infant children could be sold away from them like calves from cows. One year after the importation of Africans was halted, a South Carolina Court rules that female slaves had no legal claims . . on their children. . . . [Thus,] children could be sold away from their mothers at any age because 'the young of slaves ... stand on the same footing as other animals." (footnote omitted)).

94. See Denise C. Morgan, What is Left to Argue in Desegregation Law?: The Right to Minimally Adequate Education, 8 HARV. BLACKLETTER J. 99, 102 (1991) (" $[\mathrm{T}]$ hroughout the South ... there were anti-literacy laws [that] prohibited the education of enslaved and free Black people." (footnote omitted)).

95. See Cheryl I. Harris, Finding Sojourner's Truth: Race, Gender, and the Institution of Property, 18 CARDOZO L. REV. 309, 316-17 (1996) (concluding that "because of a Black woman's location at the margins - because she stood so far outside the normative structures of dominant society - any intervention she made was subject to being overlooked, misheard, misinterpreted, misrepresented, and ... misappropriated."); see also Laura Lane-Steele, My Brother's Keeper, My Sister's Neglector: A Critique and Explanation of Single-Sex Initiatives for Black Boys, 39 COLUM. J. GENDER \& L. 60, 94 (2020) (discussing modern day examples of prioritizing Black men over Black women and the intersectional erasure of Black women).

96. See HOOKS, supra note 40, at 42-43 (explaining that "[m]ass sexual exploitation of enslaved black women was a direct consequence of the anti-woman politics of colonial patriarchal America. Since the black woman was not protected either by law or public opinion, she was an easy target."). 
scientific proof of white superiority and the inherent inferiority of blacks to support the justification for slavery and subordination. ${ }^{97}$ "During the 1830 s the vision word 'nigger' gained common currency among whites as a term of racial disparagement." 98 The culture of racism not only took root in the South but was on full display in the North. ${ }^{99}$ For example, "[e]conomic shifts ... created tensions that resulted in widespread violence by whites against blacks, because the former believed that the latter were responsible for the cut in white workers' wages due to the increased supply of labor resulting from in-migration of Black workers. AntiBlack riots erupted in the Midwest and the Northeast fueling the widespread expansion of racial bigotry." 100

Between 1850 and the start of the Civil War, American citizens - white men and white women-reckoned more explicitly with the slavery question, the birthright citizenship question, and the divergence of interests between Northern and Southern states. In 1860 Southern states seceded from the Union. ${ }^{101}$ In 1861 , Abraham Lincoln was sworn in as president and took an oath to preserve the Union. ${ }^{102}$ The bloody Civil War ensued, with Lincoln, on one side, aiming to keep the Union intact by putting down southern states' insurrection, ${ }^{103}$ while, on the other side, the Southern states fought—not to end the Union— but to preserve slavery. ${ }^{104}$

97. Nell Irvin Painter, The History of White People 192-200 (2010).

98. See FrankLin \& Higginbotham, supra note 57, at 164; see also JoHn Hope Franklin, The Autobiography OF JOHN HOPE FrankLIN: MiRror to AMERICA 1, 373 (2005).

99. See Franklin \& Higginbotham, supra note 57, at 164.

100. See id.

101. Cynthia Nicoletti, Did Secession Really Die at Appomattox?: The Strange Case of U.S. v. Jefferson Davis, 41 U. TOL. L. REV. 587 (2010).

102. Doris KEARNS GOODWIN, LEADERSHIP: IN TURBULENT TIMES 217 (2018).

103. See Michael Kirk, States Which Seceded, EHISTORY, https://ehistory.osu.edu/articles/states-which-seceded (last visited Nov. 18, 2021); see Honorable Frank J. Williams, Abraham Lincoln and Civil Liberties: Then \& NowThe Southern Rebellion and September 11, 60 N.Y.U. ANN. SuRV. AM. L. 463, 46575.

104. Michele Goodwin, The Thirteenth Amendment: Modern Slavery, Capitalism, and Mass Incarceration, 104 CORNELL L. REV. 899, 922 (2019) ("Proponents of slavery in 
Gaining a decisive victory in battle, in 1863, Lincoln issued the Emancipation Proclamation, freeing slaves in rebel states. ${ }^{105}$ The Civil War ended in the summer of $1865 .{ }^{106}$ Shortly thereafter, states ratified the Thirteenth Amendment in December $1865 .{ }^{107}$ To restore the Union, southern states were allowed reentry upon meeting certain conditions, which were to be enforced by the Military Reconstruction Act. ${ }^{108}$ The Act established military rule in former Confederate states. ${ }^{109}$ Subsuming the Military Reconstruction Act, in 1868 and 1870, states ratified the Fourteenth Amendment, granting African Americans equal protection of the laws and the privileges and immunities of citizenship; and the Fifteenth Amendment, granting suffrage to Black men. ${ }^{110}$

\section{THE RECONSTRUCTION AMENDMENTS AND THE DUALITY OF THE}

northern states like Delaware and southern states like Kentucky vigorously fought to salvage [slavery's] explicit hierarchy and social caste system, underscoring Blacks' subordination and whites' supremacy under the law.").

105. Steven G. Calabresi \& Christopher Yoo, The Unitary Executive During the Second Half-Century, 26 HARV. J.L. \& PUB. POL’Y 667, 731 (2003).

106. Id. at 741.

107. Id. at 736 .

108. Id. at 745 .

109. Hawa K. Allan, Paradoxes of Sovereignty and Citizenship: Humanitarian Intervention at Home, 20 CUNY L. REV. 389, 414 (2017).

110. See infra IV.B. and IV.C.; see also CATHLEEN D. CAHILL, RECASTING THE Vote: How WOMEN OF COLOR TRANSFORMEd THE SufFrage MOVEMENT 5, 13 (2020) ("Throughout the antebellum period, citizenship was connected to whiteness, a status confirmed by the Dred Scott decision [in which the court held that slaves, former slaves, and their descendants were not eligible to be citizens under the U.S. Constitution]."). After ratification of the Fourteenth Amendment, the following groups were excluded from citizenship: "Indians not taxed" and children born in the U.S. to parents who were foreign ministers and parents serving in invading armies. Id. After the Fourteenth Amendment and up until 1898, the question of birthright citizenship for children born in the U.S. to immigrants arose only with reference to Native Peoples and Chinese people until the jus soli principle — birthright citizenship granting U.S. citizenship to children born on U.S. soil to parents deemed foreigners - was settled in favor of petitioner in United States v. Wong Kim Ark, 169 U.S. 649 (1898). 


\section{FRANCHISE}

The Reconstruction Amendments fundamentally changed the constitutional order in America. They created the world's first biracial democracy. Crucially, they enhanced the power of the federal government by placing the authority to define the rights of citizens in the federal sphere. Had this power been fully operationalized, the Reconstruction Amendments might have ushered in something revolutionary: a permanent change to the status of Black people from enslaved to voting citizens, participating fully in American society. Blunted by white backlash and waning political will, the Reconstruction Amendments were neutered, leaving Black people to contest, then and now, a liminal existence. This liminality makes situating the Reconstruction Amendments within their proper context a difficult, yet necessary exercise. To do justice now in understanding the key issues related to freedom, citizenship, suffrage, and equality, it is vital to center formerly enslaved Black peoples' voices.

The symbolism of personal freedom (Thirteenth Amendment), citizenship and its manifestations (Fourteenth Amendment), and political equality (Fifteenth Amendment) was pock-marked by dualities and fatal compromises that placed the welfare and property interests of white people over the natural rights of Black people. ${ }^{111}$ To adequately address the convergent and divergent interests present in the women's suffrage movement, it is critical to understand the motivations for passing and ratifying the Reconstruction Amendments and the strategies-some rational and others reprehensible - that led to the passage and ratification of the Nineteenth Amendment.

\section{A. The Thirteenth Amendment}

There were many perspectives on the institution of slavery, but none more compelling and singularly impactful than the perspective of those who were made to endure such a wretched existence. Frederick Douglass remains a key source for understanding the national tragedy of slavery, which persisted to pacify white people's social, economic, and political interests in America. ${ }^{112}$ Pointing to Lincoln's early presidential failures in not meeting the slavery question head-on, the

111. Id.

112. See, e.g., BLIGHT, supra note 31 , at xix. 
Republican Party's squandered opportunity to remake the nation by succumbing to the will of the leaders and populace in ex-Confederate states, ${ }^{113}$ and the Southern white supremacist counter-revolution against political equality for freed Black people and enfranchised Black freedmen, ${ }^{114}$ Frederick Douglass was a vocal witness to the cataclysm of the near overthrow of the Reconstruction Amendments by the Democrats intent on redeeming Southern states. ${ }^{115}$

Slavery and the slave trade were core to the legal, economic, and social system that guaranteed free labor to white property owners and planters who guarded their growing freedoms before and after the Revolutionary War. ${ }^{116}$ Many white people leaned on the term "slave" to advance the political rhetoric of the former's suffering under British tyranny. ${ }^{117}$ Frederick Douglass defined slavery as "the granting of that power by which one man exercises and enforces the right of property in the body and soul of another." ${ }^{118}$ He goes on to explain the social death resulting from slavery in the following terms:

Horses and men - cattle and women - pigs and children - all holding the same rank in the scale of social existence; and all subjected to the same narrow inspection, to ascertain their value in gold and silver... How vividly, at that moment, did the brutalizing power of slavery flash before me! Personality swallowed up in the sordid idea of property! Manhood lost in the chattelhood! ${ }^{119}$

The United States Constitution, as initially ratified, did not expressly sanction slavery; ${ }^{120}$ no matter, the custom, and practice, fertilized by the blood of the enslaved, made slaveowners prosperous and merchants and industrialists

\section{See, e.g., id. at 6,8 .}

114. Id. at 551, 557.

115. See id. at $8-9$.

116. See id. at 20.

117. See BLIGHT, supra note 31, at 149-150.

118. Id. at 20.

119. Id. at 49-50.

120. See generally U.S. CONST. 
complicit in the dissemination of that prosperity until a nation of white people could not imagine being deprived of that free labor. Despite proclaiming allegiance to the most fundamental principles anchoring this nation's Founding Document—entitling men to life, liberty, and the pursuit of happiness - white people in America, supported by the new nation's government, transformed the practice into law. Accordingly, the United States Constitution provided these men protection of their property, including enslaved Black human beings. ${ }^{121}$ Moreover, each state in the Union had complete discretion to determine voter qualifications for its residents. ${ }^{122}$ This discretion allowed states, through their electorates, to continue the evil institution. $^{123}$

There were those white Americans who did see the hypocrisy in the "identity of oppressed colonist and slaveholder."124 This sentiment illustrates a duality that helped to start a social movement to agitate against slavery. Throughout these revelatory periods, some white people grew to sympathize with captured and enslaved Black people. ${ }^{125}$ They began to understand the necessity to support the harrowing acts of resistance to slavery, ${ }^{126}$ which took the form of fighting, running, escaping, petitioning, litigating, demonstrating, fundraising, writing, speaking, and dying in the name of their natural right to liberty. Centering both the actions and the voices of Black women in resistance are equally key. Enslaved Black women responded to the torture they experienced from their white enslavers by poisoning slave owners, setting fire to the homes of slave owners, participating in and planning slave revolts, suing for their freedom citing the Bill of Rights, persuading

121. Paul Finkelman, Slavery in the United States Persons or Property?, THE AMERICAN EXPERIENCE: BluRRED Boundaries OF SlaVery 105, 119 (2012); David Azzerad, What the Constitution Really Says About Race and Slavery, HerITAGE Found. (Dec. 29 , 2015), https://www.heritage.org/the-constitution/commentary/what-theconstitution-really-says-about-race-and-slavery.

122. U.S. CONST. art. I, § 2, cl. 1.

123. Franita Tolson, Protecting Political Participation through the Voter Qualifications Clause of Article I, 56 B.C. L. REv. 159, 164 (2015).

124. See FRANKLIN \& HigGINBOTHAM, supra note 57 at 86.

125. See Richard S. Newman, The Transformation of American Abolitionism: Fighting SLAVERY IN THE EARLY REPUBLIC 1, 7 (2002); KAMINSKI, supra note 51, at $\mathrm{x}$.

126. Id. at 8 . 
slaveowners to permit enslaved Black people to serve in wars, dispensing contraception, and even committing suicide and infanticide. ${ }^{127}$ Free Black women took to the public lecture circuit, speaking about abolition of slavery, civil rights, and women's rights. The most well-known of these women were Maria Stewart and Sojourner Truth, speaking about the double bind of being Black and a woman.

The displays of courage and conviction by Black women during the antebellum period no doubt fueled a political movement to resist slavery, and the documentation of such a cause was transformative. Activists like Maria Stewart, Mary Ann Shadd Cary, and Sojourner Truth used public speaking and print media to raise political awareness about the evil institution of slavery, the journey from slavery to freedom, and the lived experiences of the journeys through racism and sexism. ${ }^{128}$ Maria Stewart, a Black woman, was the first American woman to publicly address an audience of women and men about politics, specifically attempting to influence them to join the antislavery movement. ${ }^{129}$ Mary Ann Shadd Cary, a Black woman, was the first woman to publish a newspaper in the Americas. Cary's paper "advocated that women had the right to speak and write in public, control property, hold elective office, obtain an education, and enter the professions." 130 In speeches on the antislavery lecture circuit, specifically at the 1851 Ohio Women's Rights Convention in Akron, Sojourner Truth-who was Black, a woman, a former slave, and an abolitionist - framed her very identity as the embodiment of women's rights when she proclaimed "I am a woman's rights." 131 Truth spoke of women's rights, mixing these "ideas with the challenges to slavery and to racism." 132 Even though Black women were expressly excluded from the rooms where decisions were made about the political, civil, social, and economic rights of Black people, they certainly played a role in energizing a

127. See Paula Giddings, When and Where I Enter: The IMPaCt of Black Women on RACE AND SEX IN AMERICA 39-46 (1984).

128. See generally Martha S. Jones, VANGUARD: How BLACK Women Broke BARRIERS, WON THE VOTE, AND INSISTED ON EQUALITY FOR ALL 28-33, 74-75 (2020).

129. See id. at 30-33.

130. See id. at 75 .

131. See id. at 82 .

132. Id. at 83 . 
segment of the white population to advocate, alongside free and enslaved Black people, to abolish slavery. ${ }^{133}$

The beginning of the Nineteenth Century saw the expansion of the Antislavery Movement. ${ }^{134}$ Several watershed events created interest convergence between white and Black abolitionists, which later spread generally throughout the leadership of the Northern states: (a) the realization that Southern leadership articulated as early as 1808 a looming civil war in the event any law would require emancipation of the enslaved; ${ }^{135}$ (b) passage of the Fugitive Slave Act of $1850 ;{ }^{136}$ (c) the repeal of the Missouri Compromise by the Kansas-Nebraska Act paved the way for westward extension of slavery - this event, in particular, leading to the birth of the Republican Party; ${ }^{137}$ and (d) the Supreme Court's decision in Dred Scott $v$. Sandford, which signaled the growing strength of the Southern states and the potential to delimit any power Congress had to regulate slavery in the new territories. ${ }^{138}$ The path to the Civil War was set.

The American South "was the largest, most powerful slave society in modern history." "139 Holding both economic and political power, slaveowners had the capacity to prevent abolition laws. ${ }^{140}$ Knowing this, President Lincoln attempted to cooperate with slaveowners by "advocating a program of gradual emancipation coupled with monetary compensation for the loss of property interests in enslaved

133. Id.; see also ERIC FOner, THE SECOND Founding: How THE CIVIL WAR AND RECONSTRUCTION REMADE THE CONSTITUTION 21 (2019).

134. See FONER, supra note 133 (explaining that abolition was a process that "played out over time, arose from many causes, and was the work of many individuals").

135. See Kaminski, supra note 51 at 202.

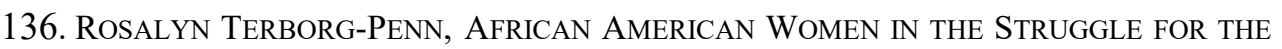
VOTE, 1850-1920, at 19-20 (1998).

137. See BLIGHT, supra note 31 , at 270-71.

138. Dred Scott v. Sandford, 60 U.S. 393 (1857) (stating that slaves were not citizens of the United States and, therefore, could not expect any protection from the federal government or the courts, and concluding that Congress had no authority to ban slavery from extending into a federal territory).

139. See FONER, supra note 133, at 24.

140. See id. 
Black people." 141 Lincoln also proposed voluntary colonization as a means to support emancipation in response to white people's desire not to live in a multicultural society in which Black people were free. ${ }^{142}$ Southern politicians who were slaveowners themselves retained the power to make the laws within the states and they actively supported retaining slavery as an institution. ${ }^{143}$

Thus, at the start of Abraham Lincoln's presidency, seven states seceded from the Union. ${ }^{144}$ Guided by a new constitution, these Southern states formed a new government called the Confederate States of America. ${ }^{145}$ War began when Confederate Troops fired on Union-held Fort Sumter on April 15, 1861. ${ }^{146}$ The war, which lasted over four years and has been universally described as the bloodiest, most devastating conflict in American history-placing soldier death tolls from between 650,000 to $850,000^{147}$ - tore the nation and its political parties apart. ${ }^{148}$ The questions were fundamental: was a popular government an absurdity?, could states secede when their leaders could not agree on a national course of action? what would be the method for handling European intervention in the face of national disagreement? ${ }^{149}$ But for enslaved Black people, there was no question, just a principle. The principle, articulated by Frederick Douglass, was to avoid a

141. Id.

142. Id. at $24-25$.

143. Id. at 25 .

144. See GoodwIN, supra note 102, at 211 (explaining after all was said and done, eleven states seceded: Alabama, Arkansas, Florida, Georgia, Louisiana, Mississippi, North Carolina, South Carolina, Tennessee, Texas, and Virginia); Abraham Lincoln and Emancipation: Timeline, LIBR. OF CONG., https://www.loc.gov/collections/abrahamlincoln-papers/articles-and-essays/abraham-lincoln-and-emancipation/timeline/ (last visited Nov. 10, 2021).

145. GoodwIN, supra note 102, at 211.

146. Abraham Lincoln and Emancipation: Timeline, LIBR. OF CONG., https://www.loc.gov/collections/abraham-lincoln-papers/articles-and-essays/abrahamlincoln-and-emancipation/timeline/ (last visited Nov. 10, 2021).

147. David J. Hacker, A Census-Based Count of the Civil War Dead, vol. 57, no. 4 CIVIL WAR HISTORY 307-348 (2011).

148. See GoodwIN, supra note 102, at 211.

149. See id. at 212. 
"negotiated peace settlement, resulting in the reestablishment of 'the white man's country,' and the obliteration of 'all the lessons taught by these four years of fire and sword." "150 "Douglass asserted that the opportunity to crush slavery, throw back racism, and reinvent the American republic around principles of racial equality 'may not come again in a century." 151

Douglass had grounds to fear a negotiated peace settlement, as the current Thirteenth Amendment almost did not occur because of the specter of irreconcilable dualities manifested by an alternative, proposed Thirteenth Amendment-The Corwin Amendment. The Corwin Amendment "would have prohibited future federal interference with slavery in the states." 152 The popular Corwin Amendment, if passed, would have allowed slavery to continue in the southern states as a measure to preserve the Union by resolving the secession crisis. ${ }^{153}$ The outbreak of the Civil War made the Corwin Amendment moot. Despite the mootness of the Corwin Amendment and the essential vanquishing of slavery, formerly enslaved Black peoples' expectations for the Thirteenth Amendment were quickly derailed by questions regarding citizenship, the state structures built on slavery, and the political, social, civil, and economic rights that would guarantee racial equality through enforcement of the Fourteenth and Fifteenth Amendments. ${ }^{154}$

Seventeen months after promoting one compromise proposal after another to assuage the Confederate Southern states, Lincoln had a legal and moral reckoning regarding the constitutional protection of slavery and the interest convergence of using a gradual emancipation strategy, ${ }^{155}$ justified by military necessity, to preserve

150. See BLIGHT, supra note 31 , at 441.

151. See id.

152. Id. at 22 .

153. Id. at $22-23$.

154. See FrankLIN \& HigginBothaM, supra note 57, at 164.

155. See LIBR. OF CONG., supra note 146 ("The Emancipation Proclamation, effective January 1,1863 , freed only the slaves in rebellious states. It put Southerners on legal notice that they would forfeit their slaves, while Northerners would retain their slave interests."). 
the Union. ${ }^{156}$ Lincoln threaded the needle of gradual emancipation within the larger context of preserving the Union, by stating the moral imperative bound up in the Emancipation Proclamation: "In giving freedom to the slave, we assure freedom to the free-honorable alike in what we give and what we preserve. We shall nobly save, or meanly lose, the last best hope of earth."157 "Military emancipation and emancipation by statute proceeded, creating Unionist state governments in portions of the South able to change state slavery laws." ${ }^{158}$ With the secession of southern states and the war bearing down in 1862, the U.S. Army ceased returning enslaved Black people to enslavers, and Congress freed all enslaved Black people who came within Union lines. ${ }^{159}$ Congress also abolished slavery in Washington, D.C. as well as in the nation's western territories. ${ }^{160}$ These actions freed only 800,000 of the 4 million enslaved Black people and did not protect them from re-enslavement. ${ }^{161}$

Despite the importance of the Emancipation Proclamation, the Civil War raged, and the victor was not yet certain. With the precarity of presidential proclamations, the persistence of state slavery laws and the probability of courts and legislatures upholding them, and white litigants seeking to abrogate proclamations, the limits on the personal freedom of enslaved Black people were destined to prevail absent a constitutional amendment to abolish slavery. ${ }^{162}$ The realization of the necessity for a constitutional amendment abolishing slavery vigorously renewed support among abolitionists, women suffragists, Radical Republicans, and especially Black people. ${ }^{163}$ Over a year of debate about the preferred method for abolishing slavery ensued, considering abolition by statute, war power, state-bystate, or constitutional amendment. At the same time, even though southern states

156. See GoODWIN, supra note 102, at 215 ("The constitutional protection of slavery could be countermanded by the constitutionally warranted war powers of the commander in chief.").

157. Id. at 242 (emphasis omitted).

158. See FONER, supra note 133, at 25.

159. See id. at $25,27$.

160. See id.

161. See id. at 26.

162. See id. at 30-31.

163. See FONER, supra note 133, at 28-29. 
were not represented in Congress due entirely to their secession, congressional sympathizers raised white supremacist arguments about the inferiority of Black people while at the same time warning that the enforcement power of the proposed amendment would force Black citizenship, Black suffrage, interracial relations, and Black land ownership on the states. ${ }^{164}$ These same congressmen further complained the white men of the southern states would be made to forfeit their land and the property belonging to them and such would reduce them to white submission and slavery. ${ }^{165}$

After Lincoln's reelection, and just about thirteen months after a draft of the amendment was circulated, Congress passed the joint resolution proposing The Thirteenth Amendment on January 31, 1865, abolishing slavery. ${ }^{166}$ As such, because of secession, Lincoln was able to recalibrate the calculus that would make ratification of the Thirteenth Amendment possible. ${ }^{167}$ Despite the raging tempest, the ratification of the Thirteenth Amendment was cause for high hopes around the potential reformation of America. It was "the first amendment in the nation's history to expand the power of the federal government, rather than restraining it." ${ }^{168}$ It also "created a new fundamental right to personal freedom, applicable to all persons in the United States, regardless of race, gender, class, or citizenship status."169 The Amendment was ratified on December 18, 1865, four days after Abraham Lincoln was assassinated. ${ }^{170}$

The Thirteenth Amendment was an essential first step toward social reform. The Thirteenth Amendment settled the question of slavery, and it provided the fundamental anchor for the second founding of the United States. It states:

\section{Section 1}

164. See id. at 33.

165. See id. at 33-34.

166. LIBR. OF CONG., supra note 146.

167. See id. at 24.

168. FONER, supra note 133, at 32.

169. Id.

170. Id. 
Neither slavery nor involuntary servitude, except as a punishment for crime whereof the party shall have been duly convicted, shall exist within the United States, or any place subject to their jurisdiction.

\section{Section 2}

Congress shall have power to enforce this article by appropriate legislation.

Unyielding resistance by enslaved and free Black people, abolitionist activism and allyship, interest convergence in the Republican Party, Abraham Lincoln's evolution toward emancipation as a military necessity, and the Northern victory in the Civil War brought about the Thirteenth Amendment, which-upon ratification-nullified the three-fifths compromise. No longer would four million enslaved Black people be counted as three-fifths of persons for the purposes of taxation and congressional apportionment. ${ }^{171}$ With four million Black people now counted alongside whites for taxation and congressional apportionment purposes, Republicans knew they had to address the potential impact of overruling Dred Scott v. Sandford on their political power in the Union, specifically in the Southern states. This point alone defines the crucial nature of the Thirteenth Amendment, because without the liberation of four million previously enslaved Black people, the Fourteenth Amendment's reform agenda could not be set in motion. That said, the immediate questions posed after the ratification of the Thirteenth Amendment were about citizenship, racial equality, economic rights to enjoy the fruits of one's labor, and Black suffrage in this new American society.

\section{B. The Fourteenth Amendment}

The era of Reconstruction spanned from 1865 to 1876 . The beginning of this era, referred to as Presidential Reconstruction, quickly revealed the political tension over the rights of Black people as citizens and the conditions under which seceded Southern states would be readmitted to the Union. ${ }^{172}$ For Black people, the Fourteenth Amendment would address anti-Blackness wrought by slavery, Civil War backlash, and racial inequality protected by state enforced systems of social and legal culture that persisted in abrogating their civil rights. While not admitted

171. See FONER, supra note 133, at 32.

172. See FranKLin \& HigginBotham, supra note 57, at 236-37. 
into congressional decision-making rooms, Black women were engaged in the public discourse about the Fourteenth Amendment and the schisms that flowed between factions of the universal suffrage movement. Notably, Sojournor Truth and Frances Ellen Watkins Harper voiced their aligned views about the rights of Black people, including Black women, even though they came out differently on the issue of priority of which group-Black men or (white) women-should access the franchise first. Truth communicated her fear that "putting power into the hands of men would add to the oppression of Black women," 173 while Harper expressed that "the greatest obstacle to the progress of Black women ... was white racism, including the racism of her [w]hite sisters." In response to white women's racist strategies and tactics supporting the "woman-suffrage-first" faction, Harper urged white women to disassociate themselves from racism and work through interracial coalition for the benefit of all, ${ }^{174}$ grounding her position with the theme: "We are all bound up together in one great bundle of humanity." 175

The overarching goal of the Fourteenth Amendment for Northern states and the majority of the Republican Party was to reinstate into the Union ex-Confederate Southern states, while maintaining the Republican Party's political power. The Republican Party "believed that the Fourteenth Amendment alone could provide the basis for a final settlement of the issue of reconstruction." 176 Presidential Reconstruction under Abraham Lincoln and then under Andrew Johnson could be described as relatively lenient and gratuitous to the Southern states. This approach to reconstruction demonstrates the power of interest convergence between Northern and Southern states to continue controversial compromises limiting the civil rights of Black people. It would take the Civil Rights Act of 1866, Republican presidential success in the 1868 election, and Congressional Reconstruction to set the stage for passage and ratification of a compromise Fourteenth Amendment that, in time, would show its implementation falling short on enforcing racial equality while permitting success in restoring full participation of Southern states in the Union.

173. GIDDINGS, supra note 127 , at $65-66$.

174. See FONER, supra note 133 , at 82 .

175. See id.

176. Earl M. Maltz, The Coming of the Fifteenth Amendment: The Republican Party and the Right to Vote in the Early Reconstruction Era, 69 CATH. U. L. REV. (forthcoming 2020) (manuscript at 14) (available at https://papers.ssrn.com/sol3/papers.cfm?abstract_id=3317813). 
Under Presidential Reconstruction, leniency in enforcing the fundamental conditions for readmission vested significant power in Southern white people to direct governance according to racist ideology built on racial hierarchy and racial oppression. Exercising this power, Democratic white leaders enacted Black Codes $^{177}$ to regulate and restrict the rights of Black people. Black Codes included: vagrancy laws, apprenticeship schemes, prohibitions on supplying testimony in courts, limitation on mobility, segregation schemes, limitations on speech, prohibitions on the possession of firearms, and voter suppression laws. ${ }^{178}$ Southern leaders relied on both state government enforcement of Black Codes as well as extra-judicial enforcement from private actors, such as white vigilante societies. ${ }^{179}$

Johnson shifted his allegiance to white Southerners and appointed provisional governors to work with Southern state legislatures - all of whom were elected by only white voters - to modify their respective state constitutions to align with the U.S. Constitution. ${ }^{180}$ With this conciliatory posture, Johnson rejected the position that Congress could constitutionally exercise federal power to regulate Black suffrage - intending to leave the issue to Democratically-controlled statesand, thus, drew the ire of Republicans in Congress by aligning with Southern white elites. ${ }^{181}$ After two years of flaccid Presidential Reconstruction, Congress passed

177. Gabriel J. Chin, The Voting Rights Act of 1867: The Constitutionality of Federal Regulation of Suffrage During Construction, 82 N.C. L. REV. 1581, 1590 (2004) (“The Southern states emphatically rejected the Fourteenth Amendment when it was proposed, and enacted a series of 'Black Codes' circumscribing the rights and status of African-Americans.”).

178. See Goodwin, supra note 104, at 936-37.

179. See Allan, supra note 109 , at 414 (discussing executive authority to deploy federal troops to respond to violations of the civil rights of Black people carried out by vigilante groups such as the Ku Klux Klan).

180. See Calabresi \& Yoo, supra note 105, at 739-40 ("[President] Johnson opened his campaign by issuing a broad pardon to most Southerners on May 29, 1865. He appointed a governor of North Carolina to call a convention in that state to amend the state's constitution in preparation for its restoration to the Union. Similar proclamations for the other seceded states followed.").

181. Id. at $740-41$. The authors explain:

Johnson's proclamations resulted in the Southern states electing extremely conservative legislative bodies: 
the Civil Rights Act of 1866, over Johnson's veto, which established citizenship for Black people and prohibited racial discrimination. ${ }^{182}$ Soon after, Congress took

[S]ome even refused to repeal their secession ordinances, much less abolish slavery or repudiate the Confederate debt, as Johnson had requested. Instead, [Southern state governments] passed black codes virtually remanding the freed people to a position not far removed from slavery and elected leading former Confederates-including Alexander H. Stephens, Jefferson Davis's vice president to Congress.

Johnson responded by urging the Southern states to ratify the Thirteenth Amendment, which abolished slavery, and by suggesting suffrage for a handful of the freedmen who owned property and could read. He then granted hundreds of additional pardons to former Confederate leaders on generous terms.

Why did Johnson, who had denounced secession as treason, do all of this? First, he mistakenly thought it his constitutional duty to reunite the South with the Union as quickly as possible. Second, he wanted to transfer power in the South from the planter aristocracy, which he justifiably hated, to a democracy of "plebians and mechanics." He was afraid the freed [Blacks] would remain "bound economically to the big planters, who therefore would be able to control them politically." Third, Johnson was, even by the standards of his day, a racist. Johnson once told Governor Fletcher of Missouri that "[t]his country is for white men ... and by God, as long as I am President, it shall be governed by white men." And fourth, Johnson wanted to be elected president in his own right in 1868 , and he wanted Southern support in that effort.

Id.

182. Civil Rights Act of 1866, ch. 31, 14 Stat. 27 (codified as amended at 42 U.S.C. $\S \S$ 1981-82 (2012)). The Civil Rights Act of 1866 sought to abrogate the many obstacles to equal treatment under the law that Black people faced by guaranteeing various civil rights to all Americans, regardless of an individual's race, such as the right to file suit, inherit real and personal property, and to make and enforce contracts. The Act was initially vetoed by President Andrew Johnson, who reasoned in his March 27, 1866, veto message, that the Civil Rights Act of 1866 wrongly favored the rights of Black people who could not possibly appreciate the full extent of the rights granted to them over immigrants to the United States:

The bill in effect proposes a discrimination against large numbers of intelligent, worthy, and patriotic foreigners, and in favor of the Negro, to whom, after long years of bondage, the avenues to freedom and intelligence have just now been suddenly opened. He must of necessity, from his previous unfortunate condition of servitude, be less informed as to the nature and character of our institutions than he 
control of the ex-Confederate states with the passage of the Military Reconstruction Act of 1867, which divided these states (except Tennessee) into five military districts to be governed under martial law. ${ }^{183}$ Termed Radical Reconstruction, Congress established "fundamental conditions," requiring ex-Confederate states to hold new constitutional conventions based on universal male suffrage and the ratification of the Fourteenth Amendment. ${ }^{184}$

The fundamental conditions stoked discord within the Republican Party as well as between Northern and Southern states. The seeds of discontent ranged from differing opinions about the federal power of Congress to regulate the "what" and the "how" of voting at the national level versus states" rights to maintain control

who, coming from abroad, has, to some extent at least, familiarized himself with the principles of a Government to which he voluntarily intrusts [sic] "life, liberty, and the pursuit of happiness."

March 27, 1866: Veto Message on Civil Rights Legislation, MILLER CTR., https://millercenter.org/the-presidency/presidential-speeches/march-27-1866-vetomessage-civil-rights-legislation (last visited Nov. 10, 2021). Johnson argued without irony that the long injustice of slavery should preclude Black people from acquiring rights that would contribute to curing them of the "unfortunate condition of servitude" from which they suffered. Id. Congress overrode Johnson's veto on April 9, 1866, though overriding this veto required removing an initially proposed provision that prohibited "discrimination in civil rights or immunities among the inhabitants of any State or Territory of the United States on account of race, color, or previous condition of slavery." CONG. GLOBE, 39th Cong., 1st Sess. 474 (1866) (statement of Sen. Trumbull). A decade later, Congress would correct the deficiency created by the removal of the prohibition against social discrimination with passage of the Civil Rights Act of 1875, although later abrogated in part by the United States Supreme Court rulings in the Civil Rights Cases of 1883. E.g., United States v. Stanley, 109 U.S. 3 (1883). The Civil Rights Acts of 1866 and 1875 marked a growing trend in the exercise of federal power that would lead to a cycle of the federal government instituting protections for Black peoples' civil rights to counteract state legislatures' continuous efforts to erode civil protections and disenfranchise vulnerable minorities. See also Cynthia Nicoletti, The Rise and Fall of Transcendent Constitutionalism in the Civil War Era, 106 VA. L. REV. 1631, 1668 (2020) ("As has been well documented by constitutional scholars, the Fourteenth Amendment was framed in order to provide a constitutional foundation for the Civil Rights Act of 1866 ... [which] defined United States citizenship as extending to all persons born in the U.S. [particularly relating to newly freed Black people] and protected all citizens in their exercise of the right to make and enforce contracts, sue and be sued, and purchase property on the same basis as white citizens.").

183. See FrankLin \& HigGinBothaM, supra note 57, at 242.

184. Id. 
over the right of suffrage, ${ }^{185}$ to imposing a requirement on only Southern states to ban racial discrimination in voting rights when Northern states would not be subject to similar requirements. ${ }^{186}$ Notably, there was also fallacious debate over the capacity and fitness of Black people to vote as well as arguments for holding their voting rights in abeyance until they learned how to acquire the skills of being free and being possessed of rights. ${ }^{187}$

These disagreements and disputes showed no signs of abating, which led to various compromises. The degree of compromise is explained by the interests at stake. Some have posited that Republicans supported suffrage for Black people based, in part, on ideological grounds. ${ }^{188}$ However, interest convergence theory provides a more cogent approach to understanding the support for or the opposition to a constitutional amendment that would protect the rights of Black people to vote. So yes, Black people and some radical Republicans fervently believed in the fundamental principle of the natural rights of man to liberty and equality, as manifested by universal suffrage. ${ }^{189}$ Others believed in pragmatism and the ability for a universal male suffrage amendment to secure Black votes for the Republican Party. ${ }^{190}$ Still, others believed that by securing in Black men a voice in the political process at the state level, there would be no need for federal protections of Black citizens. ${ }^{191}$ And others believed that a constitutional amendment was ill-advised because Black people would not be effective in countering the voting power of white Southerners, either because of a lack of intelligence or a lack of will to independently exercise the right. ${ }^{192}$

The Republican Party was engaged in the consolidation of its political power after the Civil War. In all but the first scenario-the pure ideological interest - it is apparent that the consolidation of Republican political power would

185. See Maltz, supra note 176, at 14.

186. $I d$. at 8,15 .

187. Id. at 10 .

188. Id. at 3.

189. Id. at 5-6.

190. Maltz, supra note 176, at 5-6.

191. Id.

192. Id. at 5. 
be possible with compromise. And to diverge from the interests represented in the first scenario, members of the Republican Party clung to a stated interest in reuniting with the Southern states, ${ }^{193}$ guarding against the future use of federal powers against Northern states, and partaking in a gradual approach to welcoming Black people into the voting rights fold. Needing to land on a coherent Reconstruction plan that would not offend Southern states, what once was conceived of as a constitutional amendment to enfranchise Black people, instead became a compromise amendment geared toward winding down Reconstruction. Thus, the overarching goal for Northern states and the Republican Party was to reinstate ex-Confederate Southern states back into the Union while maintaining political power. To accomplish reunification, the "Military Reconstruction Act . . . required . . . that as a prerequisite for resumption of full status in the Union, the constitutions of the unreconstructed states be rewritten to enshrine the principle of universal manhood suffrage in state law."194

Despite this directive, the fundamental conditions were neutered. Ultimately, what followed was the Fourteenth Amendment, ratified on July 9, 1868, that provided for civil rights ${ }^{195}$ of citizens and for representation based upon states' populations, and a preference for a political community of male participants, whose rights - if abridged - would only result in a loss of congressional representatives as the prescribed punishment. ${ }^{196}$ Both limited and controversial, the Fourteenth Amendment left unresolved the question of voting for Black men. It did not resolve the scope of civil rights of all citizens consistent with the constitutional value of

193. Id. at 8 ("[Republican Representative Roscoe] Conkling observed that state legislatures would almost certainly refuse to ratify a constitutional amendment that banned racial discrimination in voting rights.").

194. Id. at 14 .

195. See George Foster, Silent Terrorism: A LoOK at American Racism AND HYPOCRISY (2017) ("To enforce the Reconstruction Amendments, Congress passed the Enforcement Acts in the 1870s. The Acts criminalized the obstruction of a citizen's voting rights and provided for federal supervision of the electoral process, including voter registration. However, in 1875 the Supreme Court struck down parts of the legislation as unconstitutional in United States v. Cruikshank and United States v. Reese. After Reconstruction ended in 1877, enforcement of these laws became erratic, and in 1894, Congress repealed most of their provisions.").

196. See Laura E. Free, Suffrage Reconstructed: Gender, Race, and Voting RIGHTS IN THE CIVIL WAR ERA 125, 127-130 (2015). 
equal before law. As well, it did not effectively reapportion representation of the slave seats previously doled out to Southern states under the Constitution's threefifths clause. And egregiously, it placed all women outside of the franchise, belying equal protection under law. As such, the Fourteenth Amendment was considered a compromise, not fully satisfactory to anyone. ${ }^{197}$

\section{The Fifteenth Amendment}

The debates surrounding the Fourteenth Amendment were questions assumed to be ones between and about men. ${ }^{198}$ The assumption drew from the instinctive reflex to subordinate women and children to a second class, or even lower, status than men. Despite these assumptions, Black women were visible and active members of organized meetings and campaign rallies as well as drafters of testimony and speeches supporting and articulating the application of the Fourteenth and Fifteenth Amendments to Black people, and especially Black women. ${ }^{199}$ Black people, and particularly Black women, used the Constitution to buttress their political discourse, which was rooted in an expansive view of equality. ${ }^{200}$ This expansive view of equality manifested as coalition-based contestation of the gendered approach to the Fourteenth and Fifteenth Amendments, decisively not undercutting the interests of either Black men or white women. However, when debating the need for and the form of the mechanism to enforce the franchise for Black people and the protection of their civil rights - whether by statute or constitutional amendment - members of Congress (white men) simultaneously wrestled, consciously and subconsciously, with issues that illustrated degrees of interest convergence and interest divergence. Specifically, the Republican Party's decision to bring universal male suffrage to the foreground converged on conceptions of male hierarchy as well as a shared desire among both political parties to bring Reconstruction to a close in furtherance of the reunification of Northern and Southern states.

197. See FONER, supra note 133, at 84-86.

198. See JONES, supra note 88 , at $152-53$.

199. See TERBORG-PENN, supra note 136, at 36-41.

200. See FONER, supra note 168, at 94-95. 
Another example of interest convergence could be found on the issue of women's suffrage, which was initiated in earnest in 1848 but became a topic of heated debate when negotiations regarding Black male suffrage began. Notably, an overwhelming number of the members of Congress explicitly converged around the conception that women's suffrage was unnecessary as a means to secure their protection. ${ }^{201}$ The double burden shouldered by Black women was likely not even a consideration, much less a subject of interest divergence. Had women's suffrage taken shape during the debates over what is now the Fifteenth Amendment, pointing out intersectional discrimination based on race and gender would have met with vociferous objection. Why? Because considering women's suffrage would have provoked the suggestion that women, especially Black women, could be placed on equal footing with white men, especially Southern white men. And such a broad conception of universal suffrage starkly highlights the diverging interests between white men and white women, white women and Black men, and white women and Black women. ${ }^{202}$

To place an even finer point on the dual priorities driving congressional decision making after the ratification of the Fourteenth Amendment-confirming manhood hierarchy and bringing Reconstruction to an end-it is instructive to address the motivation of Congress to "present[] . . . a joint resolution that would

201. See Virginia Sapiro, The Power and Fragility of Social Movement Coalitions: The Woman Suffrage Movement to 1870, 100 B.U. L. REV. 1557, 1592 (2020).

202. See FREE, supra note 196, at 125-27, 164 (noting linguistical faltering when Senator James Lane read one of the drafts of a precursor to the Fourteenth Amendment). "Given these petitions [to Congress for women's suffrage from Anthony and Stanton], the problem of women's representation, and Democratic opposition rhetoric as Congress debated [the proposed resolution], hardly any congressman could fail to realize that the [proposed] resolution had a gender problem." Id. at 125 . Subsequent suffrage proposals "prominently featured gendered language." Id. at 126. When debates over draft language that preceded the Fifteenth Amendment were underway, Indiana Democratic Senator Thomas Hendrick suggested that the following language "would enfranchise 'all citizens of the United States of African descent."' Id. at 164 (quoting ConG. GLOBE, 40th Cong., 3rd Sess. 1317 (1869). The drafter, New York Republican Senator Roscoe Conkling "rejected this interpretation outright and offered a quick and simple solution to the problem[,] . . . 'insertion of the word "male," "“" concluding, "I do not think this is important enough to discuss." Id. (quoting CONG. GLOBE, 40th Cong., 3rd Sess. 1317 (1869)). 
eventually become the Fifteenth Amendment." ${ }^{203}$ Referring back to the numerous compromises embedded in Section Two of the Fourteenth Amendment, which significantly watered down recognition and enforcement of unencumbered Black male suffrage, the Republican Party was keenly aware that another amendment was needed to bolster Black men's access to the ballot, especially in Southern states. ${ }^{204}$

Unlike the Fourteenth Amendment, whose provisions were nominally directed to Northern states yet specifically directed at the ex-Confederate Southern states, the Fifteenth Amendment would significantly impact all states by taking on the suffrage question - banning racial discrimination in voting rights. With Ulysses S. Grant's election in 1868 and the securing of majorities in both the House of Representatives and the Senate, the Republican Party was provided the best opportunity to finally respond to the issue of Black male suffrage while also bringing an end to Reconstruction. ${ }^{205}$ Simply stated, the Republican Party wanted to put the race and Reconstruction questions behind it, while at the same time securing the party's legacy by manifesting a new voting base that would likely lean Republican so long as Black men had access to the ballot throughout Northern, Western, and Southern states. ${ }^{206}$

In opposing an amendment that would ban racial discrimination in voting rights, the Democratic Party proffered similar arguments made against the Fourteenth Amendment. They cited racist ideas about the capacity of Black people to live up to the weight of the franchise, the Republican grab for political power, and the federalism refrain that any federal interference with state elections would impinge on local sovereignty by divesting the several states of the right to regulate

203. Id. at 162 .

204. Id.

205. See Calabresi \& Yoo, supra note 105, at 765 ("Grant took a special personal interest in the fate of the freedmen, and he began his tenure by working 'mightily to secure adoption of the Fifteenth Amendment,' which was proposed by Congress on February 26, 1869[,] and ratified on March 30, 1870.") (quoting JEAN EDWARD SMITH, GRANT $543(2001))$.

206. Id. at 766 ("By the end of his administration, 'Grant stood watch over the South almost alone. His cabinet was uninterested, ... the Supreme Court had eviscerated the Fourteenth and Fifteenth Amendments, and the public was more interested in reconciliation than Reconstruction."') (quoting SMITH, supra note 205, at 571). 
suffrage and establish voter qualifications within their borders. ${ }^{207}$ These arguments strengthened the resolve of the Republican Party to seek a constitutional amendment, but the resolve was limited to the support of a narrow provision banning racial discrimination, leaving the provision, at best, ambiguous about federal protection of the Black man's right to vote. ${ }^{208}$ On February 26, 1869, Congress passed the Fifteenth Amendment and ratified it on March 30, 1870.

With the popularity of Ulysses S. Grant and the Republican Party's pledge to bring a speedy end to the Era, Reconstruction began to sunset in 1876. To close the chapter on Reconstruction, President Rutherford B. Hayes's Republic Administration promised to withdraw troops from the South, freeing southern politics from Northern interference. ${ }^{209}$ Republicans also agreed to pay federal subsidies and improve relations for Southern states in Washington. ${ }^{210}$

With readmission to the Union, Southern states quickly established a strategy to "redeem" their respective states by, among other things, leading disfranchisement campaigns against Black people between 1868 and 1890. ${ }^{211}$ These campaigns included: voter suppression tactics reinforced by violence, enacting Jim Crow laws, amending state constitutions to impose voting restrictions such as poll taxes, literacy tests, property ownership requirements, and moral character tests, and

207. Id. at $739-40$ and accompanying text.

208. Xi Wang, Black Suffrage and the Redefinition of American Freedom, 1860-1870, 17 CARdozo L. ReV. 2153, 2216-20 (1996) (discussing the Fifteenth Amendment Bill that was the subject of internal disagreements, disruptions, disappointments, and compromises within the Republican Party given the perception of a moderate tone and a lack of substance).

209. See Calabresi \& Yoo, supra note 105, at 779 (noting the greatest disaster of the Hayes presidency was his decision to withdraw federal troops from the South to bring an end to Reconstruction).

210. Adjoa A. Aiyetoro \& Adrienne D. Davis, Historic and Modern Social Movements for Reparations: The National Coalition of Blacks for Reparations in American (N'Cobra) and its Antecedents, 16 TEX. WESLEYAN L. REV. 687, 698 (2010) (discussing the award of reparations to former slaveholders as compensation for their economic losses suffered from the emancipation of enslaved Black people).

211. Orville Vernon Burton, Tempering Society's Looking Glass: Correcting Misconceptions About the Voting Rights Act of 1965 and Securing American Democracy, 76 LA. L. REV. 1, 10 (2015) (discussing the Post-Reconstruction dismantling of the Voting Rights of Black people). 
enacting grandfather clauses protecting the interests of otherwise ineligible white male voters. ${ }^{212}$ During this period, the Supreme Court generally upheld state efforts to discriminate against Black people and other racial minorities by creating distinctions between state actors and non-state actors, or by claiming that the judiciary had no remedial power to force states to register Black voters and other racial minorities. $^{213}$

\section{INTEREST CONVERGENCE, INTEREST DIVERGENCE, AND THE DUALITY OF COMPROMISE}

Historical context and a political background of the Reconstruction Amendments, specifically, are critical to understanding Black women's perspectives on issues surrounding slavery, women's suffrage, emancipation, and the ratification of the Nineteenth Amendment. Giving voice to the perspectives of Black women requires using an analytic construct. Accordingly, the construct used in this section is premised upon a theory of coalition-building around political action-within which interest convergence, internecine compromise, and interest divergence within and among five major constituencies will be examined. The

\section{Id}

213. United States v. Cruikshank, 92 U.S. 542 (1876); United States v. Reese, 92 U.S. 214 (1876). Justice Oliver Wendell Holmes, Jr. wrote in the Giles decision: "The traditional limits of proceedings in equity have not embraced a remedy for political wrongs." Giles v. Harris, 189 U.S. 475, 486 (1903). See also Winnett v. Adams, 71 Neb. 817, 824 (1904) ("The doctrine that equity is conversant only with matters of property and the maintenance of civil rights, and will not interpose for the protection of rights which are merely political, is supported by an almost unbroken line of authorities."). When the United States Supreme Court did challenge state-sponsored discrimination, state legislatures would adopt new statutes meant to disenfranchise Black people. Accordingly, in Guinn v. United States, 238 U.S. 347 (1915), the U.S. Supreme Court declared Oklahoma's "Grandfather Clause"-meant to allow illiterate white people (men) to vote without giving that same right to Black people (men) - unconstitutional, and the Oklahoma state legislature quickly enacted Oklahoma Laws of 1916, Act of February 26, 1916, c. 24. Section 4, which created a one-week window for new voters to register, while exempting from registration all individuals eligible to vote in 1914 (e.g., all white people (men) prior to the Guinn ruling). The U.S. Supreme Court would wait twenty-three years before abrogating this new means of state-sponsored disenfranchisement in Lane v. Wilson, 307 U.S. 268 (1939). 
purpose of this examination is to better appreciate the dualities that hampered the efforts of the women's suffrage movement.

\section{A. Interest Convergence/Divergence}

Interest convergence occurs when Black people's interest in achieving racial equality can only be accommodated when it converges with the interests of whites. Interest convergence also has currency in analyzing the dualities plaguing the women's suffrage movement, especially regarding the interests of Black women in pursuing women's equality and access to the ballot, minority populations that were tolerated so long as their interests were aligned with securing the elevation of white women to the ballot. Aspects of radical abolitionism and universal suffrage are fundamental manifestations of human rights ideology. As stated, these theoretical principles are largely morally and ethically robust. However, when applied to the conditions on the ground, these theoretical principles begin to show the impact of racial and gender realism on various groups who confronted and challenged slavery, as well as those who supported slavery during the Antebellum Period.

\section{i. Universal Humanists}

One of the more glaring omissions of the rhetoric of early-to-midnineteenth-century abolitionists and suffragists was the failure to explicitly acknowledge the plight of enslaved Black women. From the abolitionist calls for the extension of liberty to men, to the putative birth of the women's suffrage movement in Seneca Falls, New York, in 1848, the status of enslaved Black women seemed ancillary to the pursuit of liberty, merely tangential to the cause of securing political agency through the extension of voting rights. In this sense, the very symbols of the fundamental necessity for universal humanism-pseudo-freed and enslaved Black women - were secondary to other groups and political parties with discernible, divergent interests.

For enslaved Black women, institutionalized sexism and racial imperialism formed the basis of their existence in America. ${ }^{214}$ With this double burden, enslaved Black women as a group had an interest in abolitionism. Specifically, the interests

214. See HOOKS, supra note 40 , at 15. 
of enslaved Black women in abolitionism were grounded in the most basic principles: liberation from sexual exploitation and terror ${ }^{215}$ and protecting children from being sold and further exploited.

Enslaved Black women could not look to any group for protection, as abolitionists did not find it appropriate to directly and publicly expose the mass sexual terror visited upon enslaved Black women. When addressing these issues at all, abolitionists or suffragists couched these occurrences as, at best, prostitution or, at worst, stereotypes of enslaved Black women as the embodiment of sexual heathenism. These were the social constructions created by those who would not publicly recognize the contributions of Black women in the various conventions, meetings, and debates over abolitionism and women's suffrage. By silencing Black women's voices, their identity was co-opted and remade for the moral suasion interests or the political interests of others. When examining the fundamental baseline of human rights-meaning the universal and inalienable right to being equally secure in your personhood-it was enslaved Black women who should have been the focus of normative law-making and standards setting during the Antebellum Period and Reconstruction. For this reason, Black women, then and now, are closest in proximity to universal humanism, as manifested by their continued commitment to securing political agency for all people through voting rights in America. ${ }^{216}$

\section{ii. Abolitionists}

Abolitionism formed part of a larger humanitarian movement and was closely connected to religious revivalism. ${ }^{217}$ American abolitionists' general

\section{Id. at $15,27-28$.}

216. See TERBORG-PenN, supra note 136, at 36 ("[Black women] never abandoned the universal suffrage cause, as did many mainstream suffragists. As a result, African American woman suffrage strategies combined demands for Black women's right to vote and civil rights for all Black people.").

217. Bernie D. Jones, "Righteous Fathers," "Vulnerable Old Men," and "Degraded Creatures": Southern Justices on Miscegenation in the Antebellum Will Contest, 40 TUlSA L. REV. 699, 700 (2005) ("With the rise of religious revivalism and a corresponding push for social reform, abolitionism's influence grew in the North, as indicated by the founding of the American Anti-Slavery Society. Caught up in evangelicalism and rising free labor in the form of massive immigration from Europe, 
platform focused on peace, women's rights, temperance, and opposition to slavery. Abolitionists routinely asserted that slavery was contrary to the fundamental principle of American life: freedom as an inalienable right of the individual. Thus, many Abolitionists organized groups to assist slaves escaping through the Underground Railroad. ${ }^{218}$

Noted abolitionist William Lloyd Garrison co-founded the unapologetically antipolitical and devotedly pacifist American Anti-Slavery Society. ${ }^{219}$ The society funded a large cadre of abolitionist lecturers drawn largely from ministries, theological seminaries, and colleges. ${ }^{220}$ One of the society's most prominent orators was Frederick Douglass, an escaped slave without access to formal education. ${ }^{221}$

The Anti-Slavery Society splintered into three factions as interests diverged among its leadership. ${ }^{22}$ One faction remained true to Garrison's pacifist, antipolitical platform and focused on broad principles of equality, especially including meaningful participation from white women. ${ }^{223}$ Another splinter faction focused solely on slavery from a Christian reformist perspective. ${ }^{224}$ And a third splinter faction attempted to bring the issue of abolitionism into the American electoral process. ${ }^{225}$

While interest divergence operated within the Society, similar occurrences of divergence were prevalent in segments of the antislavery community that were kept at the margins because the latter-Black communities-were considered the

Northerners began to resent the existence of slavery, arguing that slavery was wrong and threatened free white labor. Slavery led to immorality and laziness, as slave societies encouraged white indolence and abuse of the blacks in their midst.").

218. See FrANKLIN \& HigginBothaM, supra note 57, at 190-93.

219. Id.

220. Id.

221. Id.

222. Id.

223. Id.

224. Id.

225. Id. 
object of the benevolence of white abolitionists as opposed to their equals. ${ }^{226}$ Thus, it was made evident to Black people, and especially Black women, that "supporting abolitionism did not necessarily mean supporting racial or gender equality."227

\section{iii. White Women Suffragists}

Garrison abolitionism, especially, helped to provide white women antislavery activists a platform to publicly pursue emancipation, women's equality, and women's suffrage. ${ }^{228}$ In this vein, Elizabeth Cady Stanton, aided in part by Quaker abolitionist Lucretia Mott, co-organized the first women's rights convention held in Seneca Falls, New York, in $1848 .{ }^{229}$ The convention attracted over 300 delegates - men and women - one of whom was Frederick Douglass. ${ }^{230}$ It was at Seneca Falls that Stanton and Mott produced the Declaration of Sentiments, modeling the Declaration of Independence, that called for the application of democratic principles in formally recognizing the social and political agency of women. $^{231}$

One of the most controversial demands appended to the Declaration of Sentiments was the immediate enfranchisement of American women, the right to vote being the lever of political agency. ${ }^{232}$ While several of the delegates balked at the inclusion of this specific resolution-including Mott herself-Frederick Douglass spoke up in support and "called the demands "simple justice.",233 In

226. Michael Poulshock, The Struggle Within the Struggle: White Supremacy in the Movement for Racial Justice, 14 TEMP. POL. \& CIV. RTS. L. REV. 259, 262-63 (2004) ("Black abolitionists were underrepresented in the antislavery societies," with many whites opposing admission of Blacks because the former feared alienating moderate whites who otherwise might join).

227. See FRANKLIN \& HigGinBotham, supra note 57, at 190-93.

228. Id.

229. See TeTRAULT, supra note 21 , at $12-13$.

230. Id. at 13 .

231. Id. at $12-13$.

232. Id. at 13.

233. See BLIGHT, supra note 31, at 196-97. 
signing the Declaration of Sentiments, he stated, "[t]here can be no reason in the world for denying to woman the exercise of the elective franchise." ${ }^{234}$ With this assist, the delegates passed the resolutions, and the campaign for women's right to vote was launched.

Underneath the surface of this auspicious first meeting was the fact that, other than Frederick Douglass's presence, there was no record of attendance by any other Black people, especially Black women. ${ }^{235}$ That the record did not reflect their presence is not conclusive; it is more likely that Black people, in general, and Black women, in particular, may have wanted to attend the meeting, but as recorders of history and those who directed them would later reveal through their writings, Black women's individual or collective presence was not even a consideration. ${ }^{236}$ While Black women's collective public presence was, at times, discouraged, their aid and influence, especially due to the capacity of Black women's clubs to support women's suffrage, was desired. ${ }^{237}$

This early course of events signals three messages that would be confirmed many times up to and during the period of Reconstruction. First, alliances between leadership of white women's suffrage organizations in relation to Black women were generally transactional. Second, Black women were generally useful as objects whose collective identity could be socially constructed to suit strategic and tactical objectives. And third, white women suffragists did not challenge the white man's government; rather, they tried to access it and would use racial artifice and fascist ideas to gain entry and secure an elevated position within the patriarchal, sexist, and capitalist structure by virtue of their whiteness.

\section{iv. Republicans}

Republicans grappled with the complexity of the nation's territorial expansion and the impact that slavery presented in consolidating the party's political

234. Id.

235. See id.; but see TERBORG-PENN, supra note 136, at 14-15.

236. See HOOKS, supra note 40 , at $130-31,149$.

237. See TERBORG-PENN, supra. note 136, at 115-17, 118-32 (chronicling the soul-sapping segregation and systemic exclusion of Black women from white women's suffrage conventions, meetings, and events as a sign of solidarity with white southern women suffragists). 
power. ${ }^{238}$ Two wings of the Mainstream Republican party jockeyed to control the political agenda: Radical Republicans and Moderate Republicans. ${ }^{239}$ Radical Republicans were committed to the ideology of antislavery. ${ }^{240}$ They supported broad reform measures to complement their antislavery platform that included federal legislation and constitutional proposals that imbued principles of equality, eschewing states' rights arguments made by Democrats and conservative Republicans sympathetic to slavery status quo. ${ }^{241}$ Moderate Republicans weighed the calculus of ending the institution of slavery against merely restricting it to

238. See DAVIS, supra note 93, at 74 (positing that "Black male suffrage - as spelled out in the Fourteenth and Fifteenth Constitutional Amendments proposed by the Republicans - was a tactical move designed to ensure the political hegemony of the Republican party in the chaotic postwar South").

239. See Wang, supra note 208, at 2156 n.9 (discussing the different labels of radical, moderate or mainstream, and conservative wings of the antebellum Republican party and describing Radical Republicans as shifting depending on the myriad issues during slavery, the Civil War, and Reconstruction, but generally defining Radical Republicans as those tending "to advocate and support more radical changes in race relations in addition to the abolition of slavery"); see also Earl M. Maltz, The Fourteenth Amendment as Political Compromise-Section One in the Joint Committee on Reconstruction, 45 OHIO ST. L.J. 933, 936 (1984) (explaining that the mainstream Republican party was split between two factions - Moderates and Radicals, both stood against immediate restoration into the Union of the defeated Confederate states and both believing that prior to restoration, some further federal protection for the rights of freed slaves was necessary. As well, both believed that the position of Unionists in the southern states needed to be strengthened and both sought to enhance the fortunes of the Republican party. Moderates, however, proposed terms far less stringent on the issue of restoration. "Moderates also disagreed with Radicals on the extent to which the federal government should protect black rights. In particular, the issue of black suffrage was a recurrent debate").

240. Maltz, supra note 239, at 935.

241. Id. at 936 ("One group-The Radicals-was willing to postpone indefinitely the readmission of the defeated southern states. Radicals argued that strong steps were necessary to ensure that the former leaders of the Confederacy would neither control the power structure of the southern states nor have a strong influence on national politics. To accomplish their goals, Radicals argued for stringent measures to disenfranchise former rebels and prohibit them from serving in public office; some Radicals ... also advocated confiscation of rebel property. In addition, Radicals pressed for strong guarantees of former slaves' rights, including the right to vote."). 
current boundaries, thus revealing intraparty tensions. ${ }^{242}$ Regardless, most Republicans coalesced around a determinism to temper, if not mute, the slave power that would result from success in freeing from bondage enslaved Black people in the Southern states. This is because enslaved Black people would be counted as whole persons for purposes of representation. During the antebellum period, most Mainstream Republicans did not necessarily conflate their antislavery platform with citizenship, anti-discrimination, or the franchise.

\section{v. Proslavery Advocates}

Antebellum slaveowners, southern aristocrats, and politicians - proslavery advocates - throughout the South sought to retain the benefits of their slavocracy to grow their agricultural interests while expanding their economic and political power base. ${ }^{243}$ Unapologetically proslavery, this group fought the sunset of the foreign slave trade in 1808 and, in its place, institutionalized the domestic slave trade. ${ }^{244}$ Southern proslavery advocates legislated slave codes that codified the repressive institution of slavery. ${ }^{245}$ White interests in their human property were protected over and above any harms that occurred to enslaved Black people. For example, among other things, enslaved Black people could be killed or murdered by slaveowners without penalty to the latter, enslaved Black women and children could be raped, enslaved Black people had no standing in courts, and enslaved Black people could not leave a slaveowner's property. ${ }^{246}$

Southern proslavery advocates sought to extend the reach of their control beyond enslaved Black people to free Black people. They succeeded in passing legislation at state and local levels to exclude free Black people from entering their states. ${ }^{247}$ Southern states, prompted by a not insignificant number of manumissions of former enslaved Black people, worried about the civil status of free Black people

242. Id.

243. See FrankLin \& Higginbotham, supra note 57, at 132-33.

244. See id. at 136-37.

245. See id. at 137-39.

246. See id. at 138-39.

247. See JONES, supra note 88, at 25. 
within their borders. ${ }^{248}$ Not wanting ideas of freedom to "go viral" among the enslaved Black populations fueling their cotton production and other capitalist interests, southern proslavery advocates enacted Black Laws, which restricted the movements of free Black people from one state to another. ${ }^{249}$ The imposition of Black Laws restricted free Black people from voting and moving around the country.

It is axiomatic that the theoretical positions of proslavery advocates relative to antislavery advocates represent interest divergence. What is not entirely evident is the degree to which these two constituencies (excepting an overwhelming majority of Black people) could point to interest convergence on Black Laws limiting the movements of free Black people and the growing antipathy in Northern, Southern, and Western states regarding the extension of the franchise to Black people.

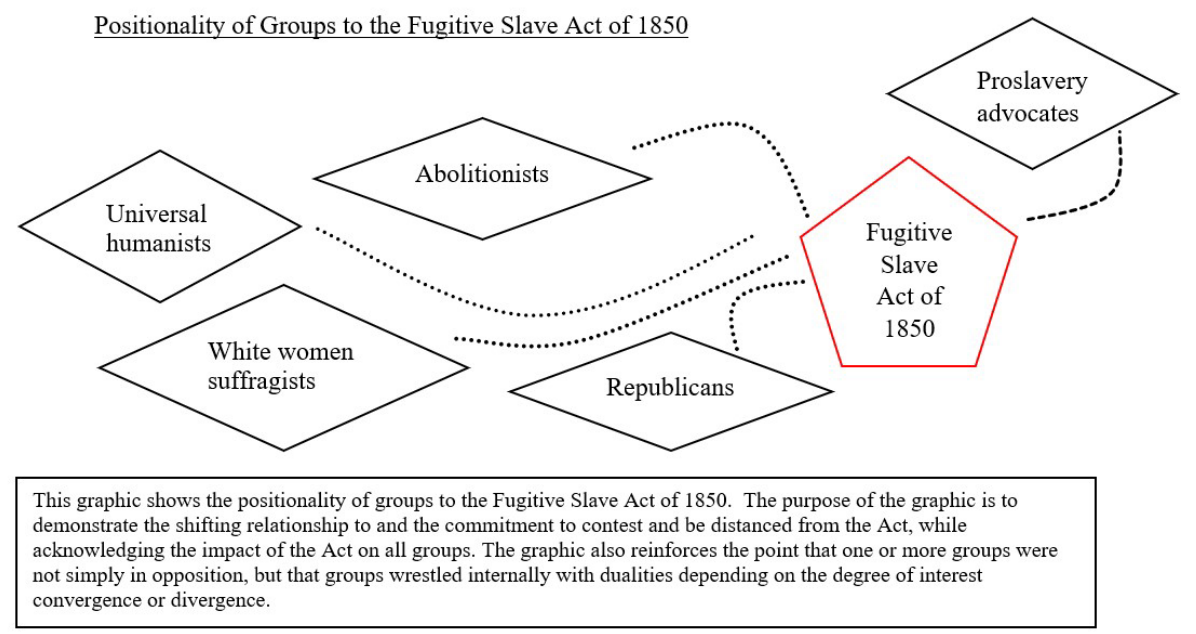

Image 1.

248. See FRANKLIN \& HigGinBothAM, supra note 57, at 161 (explaining southern states' enactment of Black Laws in response to freedom rhetoric and the events surrounding the Missouri Compromise of 1820).

249. See id. 

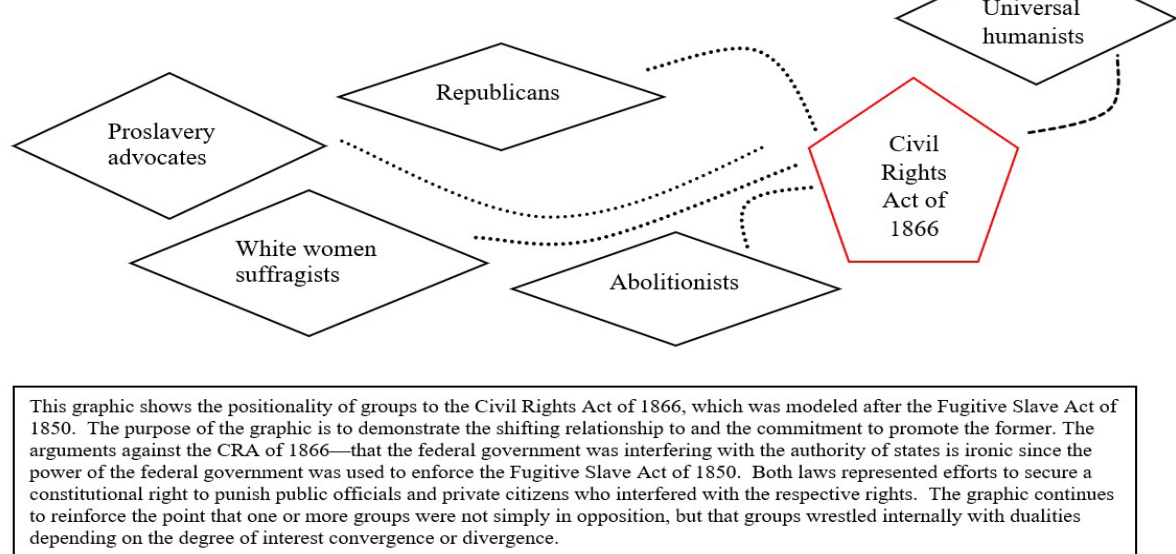

Image 2 .

\section{B. The Social and Political Impact of Internecine Compromise}

Groups engaged in coalition politics held varied perspectives on the question of slavery, and later the question of the franchise, that quickly coalesced in Northern and free states over the enactment of the Fugitive Slave Act of $1850 .^{250}$ The Act, arguably one of the most important watershed pieces of legislation that fused the convergent interest of all groups, except of course, proslavery advocates, was an inflection point about the principle of freedom in America.

The Fugitive Slave Act of 1850 was a strikingly brutal component of the Compromise of 1850, enacted to appease the Southern states and retain them in the Union in hopes of staving off a growing sectional crisis. ${ }^{251}$ The strictest fugitive slave measure ever enacted, the Fugitive Slave Act, empowered federal officials to issue warrants under which alleged fugitive slaves could be held and turned over to slave catchers, working on behalf of slaveowners who claimed the fugitive slaves

250. See Terborg-PenN, supra note 136, at 19.

251. James Oliver Horton \& Lois E. Horton, A Federal Assault: African Americans and the Impact of the Fugitive Slave Law on 1850, 68 CHI.-KENT L. REV. 1179, 1180 (1993). 
as their property. ${ }^{252}$ The law also provided that private citizens could be summoned to aid in the capture of fugitive slaves and that federal funds would cover a portion of slaveowners' expenses of rendition of fugitive slaves. ${ }^{253}$ Furthermore, the Fugitive Slave Act denied those captured the right to speak to defend themselves, habeas corpus, representation by counsel, and jury trials. ${ }^{254}$ Moreover, it gave slave catchers official rewards as payment. ${ }^{255}$ The Act meant that Southern slave states could reach into Northern and other free states and avail themselves of those states' legal systems and the use of their very citizenry to capture alleged fugitive slaves for imminent return to be dominated and controlled by the slavocracy. ${ }^{256}$

Several points of interest convergence resulted from the barbarous practice of hunting alleged "fugitive slaves." First, humanists, suffragists, and abolitionists alike could agree that the legally sanctioned kidnapping of "fugitive slaves" and freeborn blacks were anathema to the spirit of freedom as a defining principle of Independence. ${ }^{257}$ Second, Republicans, along with the three other groups, could agree that Northern and free states would be subject to Southern states' sanctioning cross border kidnapping and use of host states' legal apparatuses, in violation of states' rights principles, for the immoral and profane propping up of slavery. ${ }^{258} \mathrm{An}$ example of this interest convergence was identified by James and Lois Horton:

252. Fugitive Slave Act, ch. 60, $§ 5,9$ Stat. 462, (1850) ("And be it further enacted, That it shall be the duty of all marshals and deputy marshals to obey and execute all warrants and precepts issued under the provisions of this act, when to them directed. ...").

253. Id. at 463 ("[A]nd all good citizens are hereby commanded to aid and assist in the prompt and efficient execution of this law, whenever their services may be required; as aforesaid, for that purpose; and said warrants shall run, and be executed by said officers, any where in the State within which they are issued.") Sections 7 and 8 address the compensation of federal officers and payment of fees for the recapture of fugitives. See id. $\S \S 7-8$ at $464-65$; see id. $\S 8$ at 464-65.

254. Id. $\S 6$ at $463-64$.

255. Id. $\S 7$ at 464 .

256. Id. $\S 9$ at 465 ("[I]t shall be the duty of the officer making the arrest to retain such fugitive in his custody, and to remove him to the State whence he fled, and there to deliver him to said claimant, his agent, or attorney.").

257. See Horton \& Horton, supra note 251, at 1181-82.

258. Id. at $1184-85$. 
In most of New England, and in New York, New Jersey, and Pennsylvania, officials tried to discourage the recovery of fugitives from within their boundaries by passing personal liberty laws. Generally[,] these laws forbade the participation of state authorities or the use of state property in the capture of a fugitive. The Pennsylvania personal liberty laws of 1826 went farther, banning forcible seizure and removal of any fugitive from this state. ${ }^{259}$

Notwithstanding these personal liberty laws, "[t]he [federal] Fugitive Slave Act of 1850 made it considerably more difficult for states to protect fugitives through this kind of legislation. ${ }^{260}$

A third point of interest convergence was the experience of upheaval in Northern and free state communities. The Fugitive Slave Act and its enforcement in Northern and free states promoted civil unrest and prompted some abolitionists and humanists to shed pacification and join ranks with other community members to arm themselves with weapons to protect family, friends, and fugitives from slave catchers. ${ }^{261}$ These groups resorted to violence as a matter of self-defense, especially when they were unsuccessful in paying ransoms for previously abducted fugitives and free blacks captured in the Fugitive Slave Act snare. ${ }^{262}$ The Fugitive Slave Act also precipitated the Canadian migration, which decimated established communities, workforces, and, likely, tax revenue. ${ }^{263}$

Fourth, humanists, abolitionists, and suffragists became more militant with the indiscriminate kidnapping of free Black children. ${ }^{264}$ James and Lois Horton describe one of these events:

During the winter of 1852, a young boy, John "Blackie" Johnson[,] disappeared from Harrisburg, Pennsylvania. Months later his distraught mother learned that John had been taken to Baltimore where he was bound to a master. Further this master refused to free

259. Id.

260. Id. at 1185 .

261. See BLIGHT, supra note 31 , at 242-43.

262. See id. 242-45; see supra note 148 and accompanying text.

263. See Horton \& Horton, supra note 251, at 1187-89.

264. Id. at 1189. 
the boy unless he was paid the $\$ 100$ he claimed as transaction expenses. Blackie's mother tried to raise the money, even going door to door asking for donations. When she was only able to collect half the required sum she turned to the federal commissioner for Harrisburg, appointed by the federal court under the fugitive slave law to handle fugitive cases. In part responding to the heightened tensions and increasingly militant abolitionist protest provoked by the controversial law, the commissioner interceded on the woman's behalf, and her son was returned. ${ }^{265}$

In anticipation of the passage of the Fugitive Slave Act, "a large boisterous group of white and Black abolitionists and "fugitive slaves" met in Cazenovia, New York. They called themselves the Fugitive Slave Convention and urged the enslaved to rise in open rebellion. Their mood was symbolic of a growing spirit of defiance, fueled by passage of the new law, which was spreading among antislavery supporters."266 Even Frederick Douglass, a loyal Garrisonian during this period, was roused to part with nonviolence in response to the barbarity and inhumanity of the Fugitive Slave Act. ${ }^{267}$ According to James and Lois Horton, Douglass spoke plainly on the question of violence by stating, "[t]he only way to make the Fugitive Slave Law a dead letter is to make half a dozen or more dead kidnappers. . . . [This will] cool the ardor of Southern gentlemen and keep their rapacity in check." ${ }^{268}$ The die had been cast as interest convergence took hold.

\section{THE EXCLUSIVITY IN THE LONG JOURNEY TO RATIFICATION OF THE NineteENTH AMENDMENT: White WOMEN LEAVE BLACK WOMEN BEHIND}

Relationships between and among the various constituencies during the antebellum, Reconstruction, and post-Reconstruction periods leading to the ratification of the Nineteenth Amendment were quite complex. Accordingly, dualities as used herein and throughout are not meant to cast a single axis viewpoint. Instead, the discussion of dualities intends to demystify the facts surrounding the

265. Id.

266. Id. at 1180 .

267. Id. at 1193.

268. Id. at 1180 . 
women's suffrage movement while simultaneously accounting for the perspectives of Black women. Articulating the perspectives of Black women pushes back on the view that naming these dualities is somehow problematic because of the potential to expose controversy or conflict within the women's suffrage movement. Moreover, factual accounts of the shabby treatment of Black women by various constituencies and coalition partners during the abolition and women's suffrage movements provide an opportunity to learn from past transgressions in hopes that stronger, more sustainable relationship-based coalitions for universal suffrage in modern times can advance progressive movements for equality.

Black women are indispensable to the telling of America's attempts to build a nation; as well, these women are equally important in measuring the success of social and political movements for universal suffrage and the achievement of democratic ideals. ${ }^{269}$ It is instructive to focus on Black women as a symbol of universal suffrage because, for example, during the antebellum period - the marked intersection between the prominence of the antislavery movement and the nascent beginnings of a loosely organized women's suffrage movement-Black women arguably could be identified as one of the most vulnerable groups in American society.

During this time, Black women were either predominately part of the enslaved population or were pseudo-freed by term of years to manumission, sharecropping or completed apprenticeships, with a select few working as homemakers, with even fewer being part of a middle class. ${ }^{270}$ Regardless of actual status, Black women were not afforded the basic rights and privileges of being human, much less being afforded public spaces to perform political agency or general access to the ballot. ${ }^{271}$ Illustrating this vulnerability, overwhelmingly, enslaved Black women and girls were subjected to the gravest human rights abuses, especially during the periods between the Revolutionary War and the ratification of

269. See GIDDINGS, supra note 127 at 8 (citing Tony Morrison's statement-"'those who don't know our history, don't know their own"- on the indispensability of Black women).

270. See FrankLIN \& HigginBotham, supra note 57, at 150-51; id. at 254-55.

271. See JONES, supra note 128 at 30 (Jarena Lee, Maria Stewart, and Sarah Mapps Douglass were among the first women of any race to speak publicly on abolition and women's rights). 
the Thirteenth Amendment. ${ }^{272}$ Historians have determined that "Black women's reproductive labor became the lifeblood of the institution of slavery owing to sexual assault and forced breeding as the driver of the domestic slave trade."273

Focusing on this vulnerability, it is axiomatic to pose several fundamental questions about America's brand of democracy. For example, what was the status of Black women, what rights or privileges did they have in America, what benefits and protections were owed to them, and, most important, what did the U.S. Constitution and democracy really mean if it ignored, in many cases, and impugned in other cases, the natural rights of members of one of the most vulnerable groups within this nation's borders? If the fundamental tenet of democracy was, and is, possession of inalienable natural rights, the treatment of Black women by American society, its laws, and its legal system belied the promise of democracy. These are the questions that should have been posed in the $19^{\text {th }}$ Century and these are the same questions that are most instructive when centering Black women as symbols of universal suffrage. Then and now, Black women's battles for agency and political participation in abolitionist and women's rights circles provide the blueprint for action, movement, contestation, and revolution in service to the democratic ideal of equality for all.

The road to ratification of the Nineteenth Amendment rolls through the antebellum period's abolitionist movement. It also exposes struggles within antislavery and women's suffrage movements that pit social and political interests against universal humanism. These fractures and fissures are key to revealing the relative successes and monumental failures of a movement that ultimately doomed the second remaking of this nation. Black women suffragists and their foremothers were baptized into the abolitionist movement by their "resistance to slavery and to the systematic raping of their bodies." ${ }^{274}$ In stark contrast, white women suffragists

272. See FRANKLIN \& HigGINBOtham, supra note 57, at 150-51; id. at 243-44; see also GIDDINGS supra note 269.

273. Daina RAMEy BerRy \& Kali Nicole Gross, A Black Women's History of the UNITED STATES 86 (2020).

274. See TetraUlt, supra note 21, at 5; see also DAVIS, supra note 93 (explaining that Black women, both enslaved and free, endured rape, lash whipping violence, psychological trauma, forced family separations including alienation of their children, all forms of exploitation, dispossession of personal property, and other acts of inhumanity); see also Broussard, supra note 27 at 642 ("Truancy, self-mutilation, abortion, and birth control were options when an outright revolt or an opportunity to flee were not feasible."). 
grew up in the schools of abolitionism and antislavery activism. ${ }^{275}$ The different entry points owe to the different lived experiences of Black women versus their white women counterparts in their respective mobilizing efforts in support of universal humanism. These lived experiences reveal exactly how dualities in a movement take shape.

A primary point of departure between Black and white women suffragists, generally, was the direct experience that the former had with the institution of slavery and the shouldering of the horrors and harms that flowed from human bondage. ${ }^{276}$ Yet another point of departure was the degree to which Black women had to deal with the compound nature of racist, sexist, and elitist ideas that fueled the narrative that Black people, especially Black women, were at the bottom of the human hierarchy.

When viewing the history of the fissures and fractures in these movements, two things remained ever-present: the intertwined nature of organizational and individual racist, sexist, and elitist ideas and actions that permeated the fabric of otherwise progressive movements that guaranteed the retention of power within the white, patriarchal, imperialist society. Stated another way, if progressive movements are driven by coalitions intent on retaining white hierarchy and power within their own structures, what chance did that give this nation in moving closer toward the democratic ideal of equality for all. It is also regrettable to say that history should not judge one actor, group, or coalition too harshly, either because of the context of an era in which dominant coalition partners trafficked in the currency of sexism, nativism, ethnonationalism, and class or used dominance and power to fuel odious divisions to intentionally and explicitly reinforce white supremacy and white hierarchy. ${ }^{277}$ This is apologist and counter-productive in ultimately reframing a comparative narrative of the actions of actors, groups, or coalitions so as to trace the positive and negative impacts of those actions on their coalition partners and the larger movement in order to instantiate interdependent paths forward for coalition members.

Figures like Elizabeth Cady Stanton, Susan B. Anthony, and Lucretia Mott adopted the exclusionary leadership examples demonstrated by white men

275. See TetraUl, supra note 21 , at 11-13.

276. See DAVIS, supra note 93.

277. Cf. Sapiro, supra note 201, at 1606. 
abolitionists. ${ }^{278}$ Stanton promoted a brand of feminism generally premised upon self-interest. ${ }^{279}$ Her approach singularly focused on middle-class white women's political empowerment. ${ }^{280}$ The strategies she deployed focused on connecting with other women within the abolitionist movement, especially white women, who shared the same vision. ${ }^{281}$ To the degree that Black women could further her goals and objectives, Stanton was a coalition partner of the transactional kind, limiting Black women's involvement in meetings, conventions, speaking and podium appearances, and public advocacy on behalf of women's equality and women's suffrage. ${ }^{282}$ Susan B. Anthony shared the same vision and approach to Black women's stature and participation in the women's equality and women's suffrage movement. ${ }^{283}$ Accordingly, it is fair to conclude that Stanton's and Anthony's leadership approach to antislavery and anti-sexism activism were grounded in patriarchy, clearly demonstrating the limits of interest convergence during the antebellum period, leading into the Civil War and displayed in full force during the Reconstruction Era.

278. See DAVIS, supra note 93, at 47-48, 57-59, 63. Lucretia Mott, a prominent abolitionist woman, and a greener Elizabeth Cady Stanton were relegated to a curtained sidebar at the 1840 World Anti-Slavery Convention in London by a majority vote from male delegates. These women returned the exclusionary favor by not ensuring the presence of Black women at the 1848 Seneca Falls Convention and, more pointedly, not referencing Black women in Convention documents. Moreover, at the 1851 Women's Convention in Akron, Ohio, Sojourner Truth delivered her “Ain't I a Woman?" speech to bursting cheers; but on the second day of the convention, leading white women urged Frances Dana Gage, the presiding officer of the Akron Convention, to prevent a Black woman from speaking because they did not want her to have a voice at their convention.

279. Id. at 53-55. (Elizabeth Cady Stanton's and Lucretia Mott's Declaration of Sentiments, with its resolution for women's suffrage, spoke explicitly to the consciousness of the middle-class white woman's dilemma, all but ignoring the predicament of white working-class women, while ignoring the condition of Black women-enslaved or freeborn - while even before the Great Schism blatantly manifesting racist ideas and actions); see also Sapiro, supra note 201, at 1580.

280. See DAVIS, supra note 93, at 47-48, 57-59, 63.

281. Id.

282. See generally DAVIS, supra note 93.

283. Id. 
An example of interest convergence turning into interest divergence was the divide in the women's suffrage movement following the debates and then ratifications of the Fourteenth and Fifteenth Amendments. In response to the support for Black men's suffrage, Stanton and Anthony adopted a political strategy of "utilizing racist and elitist rhetoric that emphasized the need for women to have the ballot in order to protect them from newly enfranchised freedmen and immigrant troglodytes." 284 When Stanton and Anthony referred to women who needed protection, they implicitly, if not explicitly, were referring to white women. This name-calling strategy coupled with the more insidious courting of financial and political support from Democrats - then the party of the white supremacist Southwas intentional and targeted to draw on racist ideas that would attract southern white women to identify with Stanton's and Anthony's new brand of white women's suffrage advocacy. ${ }^{285}$ On this divergent path, Stanton and Anthony exchanged universal suffrage ideals for a white women suffrage first platform, which reinforced their joint opposition to the Fifteenth Amendment, and aligned with public figures openly hostile to Black civil rights. ${ }^{286}$ The Black feminist author, bell hooks, explains:

The fact that the majority of white women reformers did not feel political solidarity with black people was made evident in the conflict over the vote. When it appeared that white men might grant black men the right to vote while leaving white women disenfranchised, white suffragists did not respond as a group by demanding that all women and men deserved the right to vote. They simply expressed anger and outrage that white men were more committed to maintaining sexual hierarchies than racial hierarchies in the political arena. Ardent white women's rights advocates like Elizabeth Cady Stanton who had never before argued for women's rights on a racially imperialistic platform expressed outrage that inferior [the ' $n$ ' word] should be granted the vote while 'superior' white women remain disenfranchised. ${ }^{287}$

284. PAUla J. GidDings, IDA: A SWORd AMONG Lions 350 (2008).

285. TETRAULT, supra note 21 , at 24-25.

286. Id. at $28-29$.

287. See HOOKS, supra note 40. 
The very public action to embrace racist and patriarchal ideas and strategies in support of "white women first" suffrage tactics demonstrates the duality of a movement as exhibited by Susan B. Anthony and Elizbeth Caty Stanton. Confiding to Ida B. Wells in conversation, Anthony candidly admitted, she did not want Frederick Douglass to attend a National American Women's Suffrage Association (NAWSA) meeting in Atlanta because she did not want him "subjected to any humiliation there, nor did she want anything to get in the way of bringing the southern white women into the suffrage association."288 Yet, Anthony, a former abolitionist with ties to Black reformers, also publicly and privately performed displays of disparaging racism while engaging with the act of racism as a strategy to justify obtaining the ballot for "white women first." 289 Stanton and Anthony leveraged an "ends justifying the means" or a transactional coalition approach to the women's suffrage movement, rationalizing that white women would use the vote to eventually resolve the race question. ${ }^{290}$

Years later, Alice Paul and Lucy Burns, in planning the 1913 Women's Suffrage Parade, exhibited similar dualities on their women's suffrage watch. Specifically, Paul and Burns planned a massive women's suffrage parade to coincide with the inauguration of President Woodrow Wilson. ${ }^{291}$ Like her foremothers Anthony and Stanton, Alice Paul intended the 1913 Women's Suffrage Parade be white women only or nonwhite or foreign women, depending on whether this would help or hurt the cause of white women's suffrage. ${ }^{292}$ White women planners then addressed who should be included, especially amongst women of color-specifically Native women, Chinese women, and Black women. ${ }^{293}$ After planning and deliberation, Paul decided not to extend offers of participation to Black women, while at the same time stoking rumors that if Black women participated, the parade would be segregated. ${ }^{294}$ Black women from across the country and their allies protested in such numbers that NAWSA headquarters rescinded exclusionary

288. See Giddings, supra note 233, at 350.

289. Id.

290. Id.

291. CAHILL, supra note 110 at 98.

292. See id. at 99-100.

293. See id. at 100-02.

294. See id. at 102-03. 
participation. ${ }^{295}$ It is well documented that Black women, as exemplified by the experience of Ida B. Wells-Barnett, were instructed, urged, and then directed to march in the back of the parade procession, reinforcing racist acts and, again, surfacing yet another duality in the women's suffrage movement. ${ }^{296}$

Without question, there were many disagreements about the strategies and tactics proposed to end slavery and to secure universal suffrage, which would be expected from any grand-scale network of coalitions within reform movements. ${ }^{297}$ Moreover, it is undeniable that leaders would clash over what approaches should be deployed to reach suffrage goals and objectives. ${ }^{298}$ As well, there is little or no argument that with any asymmetric and formidable problem or challenge, then and now, there would necessarily be equally asymmetric and formidable solutions to respond to those problems and challenges. But contravening the ethical framework supporting your coalition and those of your partners while simultaneously cannibalizing the ultimate goal of the movement for the sake of social and political expediency transgresses the obligation to be accountable to partners within the coalition. This lack of accountability, among other factors, provides a window into the schism that marked the setbacks experienced by the women's suffrage movement and frustrated the progress of universal suffrage. Looking to how coalitions are formed and nurtured and using Black women's successful experiences with coalition building provides another basis for centering Black women as symbols of the democratic ideal of equality for all.

Movements are destined to be fragile if they are comprised of only individual activists and coalitions that are transactional in nature. Movements have the opportunity to be more sustainable and durable if the core of the movement is buttressed by coalitions built on relationships. Relationship-based coalitions are achieved when partners express: (1) a willingness to learn about and promote each member's mission in order to reach mutual benefit and common purpose by sharing

295. See id. at 103.

296. See id. at 104-10.

297. See Sapiro, supra note 201, at 1601 ("In the late 1860s, the question of coalitions between race and gender inclusivity was often more about tactics and perceived effectiveness than about rejection of woman suffrage in principle.").

298. Id. at 1603-04 (explaining that much of the Republican Party threw its weight behind a constitutional amendment extending the vote to Black men, largely for critical strategic reasons, one of which being the very slim margin by which presidential candidate, Ulysses S. Grant, won his election). 
risks, responsibilities, resources, and reward; (2) a commitment to disrupt existing societal power relations to redistribute decision-making power to those members identified as the focus of the coalition work or those experiencing the greatest inequities; and (3) an agreement by partners to be accountable to other members for what is learned through coalition. ${ }^{299}$

In building a relationship-based coalition in furtherance of universal humanism, whether premised on radical methods or incremental expansion methods, coalition members would move past fragility to more stable, sustainable terrain by pledging allyship in lieu of performing it. ${ }^{300}$ This requires a generally accepted and practiced approach to building relationship-based coalitions. Thus, coalition partners must be socialized to expect an intimate, trusting relationship that can be described as collective, public, and demonstrative of participatory inclusion.

299. Compare Amy C. Edmondson et al., Cross-Silo Leadership, HARV. BuS. REV., MayJune 2019, at 130-39, https://hbr.org/2019/05/cross-silo-leadership (discussing the importance of breaking down silos to help people collaborate across boundaries by, among other things, valuing horizontal interfaces that encourage members of diverse teams to proactively take on the perspectives of others), and Arthur T. Himmelman, On Coalitions and the Transformation of Power Relations: Collaborative Betterment and Collaborative Empowerment, 29 AM. J. COMTY PsYCH. 277, 278, 284 (2001), https://www.researchgate.net/publication/11895715_On_Coalitions_and the Transformation_of_Power_Relations_Collaborative_Betterment_and_Collaborative Empowerment (opining that transformation from collaborative betterment coalitions to collaborative empowerment coalitions could occur by reforming coalition power relations by providing opportunities for people to practice becoming more powerful in a democratic manner and growing comfortable with being responsible and accountable to others), with MARIAME KABA, We Do This 'TIL We FreE Us: ABOLITIONIST ORGANIZING AND TRANSFORMING JUSTICE 175, 178-80 (2021) (“Community matters. Collectivity matters ... And if we can't get along with each other, and we can't take responsibility for what we do with each other, then what the hell are we doing? ... Please be part of the community of folks who are building an accountable community with each other.") ("When we are in relationships with each other, we influence each other.") ("Political commitments [should be about] developing stronger relationships with people and transforming harm ... [on fundamental levels of the lived experience not just theory-building through the promotion of abstract ideas separated from the struggle].").

300. See Himmelman, supra note 299 at 279 ("[I]t is rare for a coalition to become a 'learning community' in which all organizations, including those providing funding for coalition efforts, agree to share and be accountable for what is learned [and] how it will be applied in assisting the coalition [to] achieve its stated purpose."). 
In the case of universal suffrage, relationship-based coalitions could be strengthened through the constant shifting and changing of cycles of priorities with issues like debates about citizenship, privileges and immunities, and political agency, or with audiences like leaders of social organizations, workers unions, politicians, and community leaders.

In contrast to a relationship-based coalition, a transactional coalition can be defined as a group of members or organizations assembled together for a discrete purpose to pursue a mutually beneficial goal or objective. ${ }^{301}$ In a transactional coalition, members or organizations often represent different interests. ${ }^{302}$ Specifically, members - after performing a cost-benefit analysis-make determinations that the net interests to them or their organizations are best served by joining with others to pursue a specific outcome. ${ }^{303}$ With a transactional coalition, the probability is high that some members will leave the coalition or become passive advocates when they achieve their purpose for joining. Channeling Derrick Bell's theory, this point on the coalition spectrum can be referred to as the point of inflection - when interest convergence ceases, and coalition partners face a decision matrix that places them and the institutions they represent before the interests of the larger coalition. ${ }^{304}$

301. See Sapiro, supra note 201, at 1560 (defining social movement, in a limited frame, as "coalitions of organizations, groups, and individuals who come to overlap and share concerns and approaches to addressing core political issues as part of a movement coalition but do not necessarily share all key concerns, priorities, or action repertoires, considered independently," and then concluding that "[t]his situation obviously makes movement coalitions fragile").

302. See id.

303. See id. at 1561 ("[N]etworks or coalitions of different organizations, groups and individuals [have] overlapping but different interests... strategic, or tactical preferences" and these coalition partners "relate to each other and to the core concerns of the [larger coalition] in a variety of ways ..." For example, some coalition partners "may work together only from time to time, while others may do little more than share common communication networks." With respect to women's suffrage, coalitions "consisted of a large field of organizations, groups, and individuals who worked for woman suffrage, sometimes in concert or coalition with each other, sometimes in more parallel or informally intersecting activity, and sometimes in disagreement or conflict with each other.").

304. See HOOKS, supra note 40 and accompanying text. 
Another perspective on transactional coalitions is the use of coalition resources to address a specific issue impacting only a segment of the coalition's membership. ${ }^{305}$ What separates this approach to coalition building and maintenance from a more relationship-based, more invested coalition is a long-view commitment to a transformational vision of change, based on the redistribution of power, recognized and accepted by all coalition partners and the institutions they represent. ${ }^{306}$ Relationship-based coalitions rely on transformational processes in which partners are invested in achieving, not their own objectives exclusively, but the objectives of other members in the coalition. ${ }^{307}$ Consequently, some coalition members may commit relationally, while other members of the coalition will only commit transactionally. This renders the coalition essentially transactional in nature once the coalition efforts reach the point of inflection for certain members, especially when those members hold power as determined by resources or influence. It is equally possible that members can move in and out of a transactional coalition based on the specific task or issue, but this kind of plug-and-play partnership has the potential to do the following: minimize trust between and among coalition partners; reduce the effectiveness of the advocacy or task related to the efforts, not to mention the probability of diminishing transformational change efforts; and delimit future progress when coalition action is most necessary.

Without a commitment at any point on the spectrum to a relationship-based coalition, the logical ending place of interest convergence is interest divergence. When the objective of the more powerful party within a transactional coalition-

305. See Himmelman, supra note 300, at 279-84 (discussing the use of resources to achieve collaborative betterment versus the more transformative collaborative empowerment of those who are the target beneficiaries of the coalition work).

306. See id. at 281 (explaining that betterment coalitions, as opposed to empowerment coalitions, control and guide, as "they are not designed to transform power relations or produce long-term ownership in communities by significantly increasing communities' control over their own destinies. Most coalitions can be classified as betterment processes; as such, they reflect the same processes" that reinforce existing structures of control).

307. See id. at 282 (describing empowerment, in part, as "an increase in the capacity to set priorities and control resources that expand self-determination ... within communities or among constituencies and, after establishing mutually agreeable power relations, invite the participation" of institutional partners. Thus, "[e]mpowerment coalitions include a strong emphasis on community organizing, grassroots leadership development, and increase the ownership and power of those primarily affected by the coalition's activities"). 
which is formed through interest convergence - has been reached, absent a shared ethos or a defined collective vision for a universal outcome, commitments cease even though outcomes for the least powerful coalition partners remain unrealized. For Stanton, Anthony, and others who shared their vision, the duality rested in the stance they took in relation to universal suffrage. Their decision - to pursue entry of only white women within the existing system of patriarchy-cemented their choice of a core value and a brand of advocacy that raised racial hierarchy over universal humanism in pursuit of their singular objective - white women's suffrage.

Unpacking these examples of both dualities and internecine compromises exposes the limitations and shortcomings of transactional coalitions and interest convergence. It also signals the importance of coalitions built upon relational, transparent, and collective frameworks. ${ }^{308}$ The lessons learned from the history of tumult and conflict of the movements to abolish slavery and to enfranchise women are myriad, but three stand out prominently as cautionary principles. First, absent a radical shift in how we value the perspectives of vulnerable voices in our democracy, equality in America will always be measured by the fact that racism, sexism, and otherizing isms organize politics, the economy, and social life, experiences, and relationships. ${ }^{309}$ Second, commitment to a good cause does not excuse complicity with those who would engage in evil or unethical conduct. ${ }^{310}$ And third, social movements and the coalitions that are built around them should be focused on fundamentally transforming society to embrace collective approaches to strengthening democracy through inclusive participation. ${ }^{311}$

The objective should be to learn about the fault lines that accompany the veneration of people and the mythology surrounding them. With more robust investment in developing relationship-based coalitions collectively acting, moving, and contesting the status quo during the women's suffrage movement, the greater

308. Amna A. Akbar et al., Movement Law, 73 Stan. L. Rev. 821, 860 (2021).

309. See generally, JONES, supra note 128 at 124; see also Serena Mayeri, After Suffrage: The Unfinished Business of Feminist Legal Advocacy, 129 YALE L.J. F. (2020) (discussing the women's suffrage movement and the Reconstruction-era disintegration of an abolitionist-feminist alliance).

310. See Jones, supra note 88 , at 77.

311. See Poulshock, supra note 226 and accompanying text; see also Akbar et al., supra note 308, at 844-845 ("[L]aw often reproduces hierarchal power relations, [thus making it] essential that we pay attention to grassroots struggles for transformation."). 
the opportunity to develop blueprints for the perpetual striving toward the democratic ideal of equality for all.

America's version of equality is exclusive by historical and modern design, and that design is intentional. ${ }^{312}$ The political, social, and economic battles over birthright citizenship and access to the ballot are stark examples of the embeddedness of ascriptive hierarchies that illustrate this exclusivity. From the protestations by Southern Democrats that emancipation and later the Thirteenth Amendment worked a taking of property through abolishing the enslavement of Black people to the denial, in practice, of any constitutional protections owed to Black people within state borders, the white hierarchy relegated Black people to only liminal existences, granted solely for the purposes that benefitted the selfinterest of the former. Examples of the exclusivity of equality include the establishment of Black Codes, Jim Crow legislation, and the racist campaigns by some prominent white women suffragists that succeeded in disfranchising Black men, even after the ratification of the Fifteenth Amendment, and that left Black women disfranchised, adrift, and alone, after the ratification of the Nineteenth Amendment. ${ }^{313}$

312. See StaCey Abrams, OUR Time Is Now 11 (2020) ("American democracy has always left people out of participation, by design."); see also Daniel S. Harawa, Sacrificing Secrecy, 55 Ga. L. Rev. 593, 650 (2021) ("A growing concern among racial minorities in America exists regarding whether they can ever truly achieve justice in a system that has racism baked into its core."); Rebecca Klar, Steyer Endorses Reparations Bill, Commits to Working with Jackson Lee, 2020 The Hill 509179, 2020 WL 4287972 (July 27,2020 ) ("The structural racism stemming from slavery that is baked into the founding and the foundation of our nation has permeated all aspects of American life."); Rhonda V. Magee, "If You Plant Corn, You Get Corn": On Mindfulness and Racial Justice in Florida and Beyond, 90-APR Fla. B. J. 36, 38 (2016) (citing EDUARDO BONILLA SILVA, RACISM WITHOUT RACISTS: COLORBLIND RACISM AND THE PERSISTENCE OF RACIAL INEQUALITY UN THE United STATEs (3d ed. 2014) for the proposition that "even more troubling is that in these same "cultures" in which racial messages dare not be called racist messages, we see evidence of systemic and institutional racism baked into our legal structures, operating irrespective of individual intent").

313. See TERBORG-PENN, supra note 136, at 56 ("[As] racism became institutionalized nationwide ..., [t] $]$ he woman suffrage movement was gaining national momentum, and with it the leadership sought to recruit white middle-class, native-born women at the expense of Black women, immigrant women, and working-class women of all races."); see also ABRAMS, supra note 312, at 21. 
In establishing and expanding relationship-based coalitions around movements for equality that feature inclusiveness, it is essential to address the historical context and its connection to contemporary social, political, and economic struggles that are ongoing and animating current progressive advocacy and collective community engagement. Moreover, part of the engagement with coalition members must be an exposition of how law's architecture currently abhors a change to the existing hierarchy. Thus, along with centering coalition efforts on radical transformations that would extend and expand democratic participation to society's most vulnerable, equally radical transformations of law and legal systems are an inevitable imperative.

The women's suffrage movement is replete with illustrations that the ends cannot justify the means, especially when the means involve replicating white patriarchy, racism, and sexism to achieve a narrow outcome for but one segment of the coalition. The Anthony/Stanton transactional approach to coalition-building leveraged the same racist and sexist tropes that set the stage for the Great Schism. ${ }^{314}$ Had Anthony and Stanton-instead of adopting the patriarchal playbookchanneled the visceral experiences of all women who were scorned and castigated for their participation in abolitionist and women's rights movements they would likely have created room for diminishing the negative impact of racism on their movement and, in turn, would have established a framework for a successful legacy supporting universal suffrage.

Forging a relationship-based coalition that transcends single issues and/or narrow outcomes encourages coalition members to invest in problem-solving and advocacy from another coalition member's perspective. Instead of centering self (or a particular coalition member), the best practice to build a relationship-based coalition is to come at the coalition's vision through another member's experiences.

315 The goal is to see how the experience of those who are "othered" or subordinated informs the self, through the practice of de-centering. ${ }^{316}$ Moving away from transactional coalition-building and moving toward relationship-based coalitionbuilding requires long term, visionary thinking toward legacy transformations, with a focus on each members' adoption of a pledge like the following: "If I can't get to
314. See
Ta-Nehisi
Coates,
The
Great
Schism, https://www.theatlantic.com/national/archive/2011/10/the-great-schism/246640/ (last visited Aug. 14, 2021).

315. See Edmondson, supra note 299, at 130-39.

316. See id. 
my own Promised Land, but I can help someone else get to their Promised Land, then my partnership in the struggle has been effective." 317

Women's suffrage was achieved on August 18, 1920, with the ratification of the Nineteenth Amendment to the U.S. Constitution. The Nineteenth Amendment states:

The right of citizens of the United States to vote shall not be denied or abridged by the United States or by any State on account of sex.

Congress shall have power to enforce this article by appropriate legislation. ${ }^{318}$

The transactional approach to coalition-building in the women's suffrage movement, in large part, is responsible for the ultimate failure to achieve universal suffrage. Notably, "[i]n spite of the efforts to implement their political rights ... Black women in the South were disfranchised in less than a decade after the Nineteenth Amendment enfranchised them." ${ }^{319}$ While their disfranchisement in the South was by law, their disfranchisement in the North was by deed and by action resulting from white patriarchy. ${ }^{320}$ After white women secured the vote for themselves, they left behind their partners-Black Women, Latinx Women, Immigrant Women, and Asian Women-making clear their transactional commitment to women's suffrage, being bound up only to the point of interest convergence. Undaunted by being "ghosted" by white women suffragists in some form or another from 1820 onward, Black women, among other women of color, have stayed the course in support of universal suffrage, specifically, and universal humanism, generally.

317. See Mayeri, supra note 309 at 23 ("Murray believed that 'the rights of women and the rights of Negroes are only different phases of the fundamental and indivisible issue of human rights.' 'American history' taught the 'costly lesson' that 'human rights' could not 'be affirmed for one social group and ignored in the case of another without tragic consequences."”).

\section{U.S. CONST. AMEND. XIX.}

319. See TERBORG-PENN, supra note 136, at 19, at 11-12 ("The process took less than half the time it had taken for Black men to lose their votes after the ratification of the Fifteenth Amendment in 1870.").

320. See id. at 12. 
The continuing legacy of Black women is their commitment to relationshipbased coalition-building as an organizing principle built on trust, loyalty, consensus building, directness, and interdependence. ${ }^{321}$ These characteristics of Black women's relationship-based coalition building form the genealogy of their long, and often unsung, participation in social justice movements, in particular the movement for universal suffrage. ${ }^{322}$ Now is an opportune time to consider Black women's

321. See Mary-Elizabeth B. Murphy, Jim Crow Capital: Women and Black FreEDOM STRUGGLES IN WASHINGTON, D.C., 1920-1945, at 3 (2018) (explaining that "[d] uring the 1920s, [B]lack women tapped their connections in churches, fraternal orders, labor networks, neighborhoods, and the women's club movement to organize and sustain their political campaigns. In particular, middle-class [Black women] used their networks in the National Association of Colored Women (NACW) and its local chapters throughout the nation as a building block to create new organizations and recruit constituents .... [Black] [w]omen tapped their organizing culture to address the growing crisis of interracial police violence. The Great Depression led to widespread unemployment and poverty for [b]lack residents across the city (referencing the District of Columbia), prompting [Black] women to argue that all citizens of the United States deserved economic justice, which included decent employment, fair wages, family support, and government protections in cases of unemployment and old age"); see also TERBORG-PENN, supra note 136, at 82-83 (discussing the [Black] women suffrage mobilization developed with the formation of a national Black women's club movement "to push for the enfranchisement of all Black women as a means to protect Black communities, and for the reenfranchisement of Black men whose votes had been stolen from them[,]" a coming together that was "clearly nationalist in character, demonstrating the significant differences in political awareness between Black and white suffragists").

322. Mayeri, supra note 309 at 512. The unsung, until recently, work of Pauli Murray is instructive. Mayeri writes, "Impelled by the historical memory of the womansuffrage split, Murray's activism and writings in the 1960s and early 1970s endeavored to bridge gaps between movements for racial justice and for sex equality. Murray emphasized the centrality of women's activism to racial-justice movements and protested the exclusion of black women from the speakers' dais at the 1963 March on Washington, declaring: 'The Negro woman can no longer postpone or subordinate the fight against discrimination because of sex to the civil rights struggle but must carry on both fights simultaneously,' because women's 'full participation and leadership' was 'necessary to the success of the civil rights revolution.' And she adamantly refused to subordinate or subdivide her complex identities as a 'Negro woman' of mixed racial heritage, a civil-rights lawyer, a labor advocate, and a champion of universal human rights. To the reawakening feminist movement she brought the legacy of racial-justice activism, calling for a women's March on Washington if the EEOC failed to enforce 
approaches to relationship-based coalition-building along the lines of integrating their core values - as opposed to co-opting them — with the diverse cultural narrative arcs of partners having similar interests in building a legacy for sustainable universal suffrage.

\section{BLACK WOMEN AS COLLECTIVE AND COALITION PARTNERS AND Their PERPETUAL COMMITMENT TO ACHIEVING UNIVERSAL SUFFRAGE}

This article is about, in part, the historical context of the Nineteenth Amendment using the lived experience of Black women as a centering reference. It identifies salient reasons - notably tenuous, transactional coalitions - to explain why the women's suffrage movement failed Black women before, during, and after Reconstruction. Yet, it is also about how Black women's expertise in coalitionbuilding, then and now, offers a template for bridging social, economic, and political divides to advance a sustainable movement for equality, beginning with the important objective to attain universal suffrage. The dedication and commitment of Black women to sustained organizing for women's rights and women's suffrage from the antebellum period until the present entreats us to acknowledge them as symbols of universal suffrage. ${ }^{323}$

Title VII's sex discrimination prohibition. When racial, generational, and ideological differences threatened to divide feminists, Murray urged intergenerational and interracial alliances." Id.

323. See JONES, supra note 128 at 149 (quoting one of the founders, Josephine St. Pierre Ruffin, who communicated the purpose of the National Association of Colored Women, which was this: "Our woman's movement is woman's in that it is led by and directed by women," which Dr. Jones explains was "[n]ot to be confused with organizations driven by a single interest or exclusive in its goals." Dr. Jones relies on the words of St. Pierre Ruffin to explain the organization's vision of universal humanism, which is this: "It was for the good of women and men, for the benefit of all humanity." "We want [and] we ask the active interest of our men, and, too, we are not drawing the color line; we are women, American women, as intensely interested in all that pertains to us as such as all other American women." "We are not alienating or withdrawing, we are only coming to the front, willing to join any others in the same work and cordially inviting and welcoming any others to join us"). 
Black women, as a collective, have an unsung history of fighting for freedom and suffrage. ${ }^{324}$ From blood-soaked battles over slavery and states' rights, and protests and marches for inclusive citizenship and enfranchisement, to national reform movements in response to Jim Crow and lynching's voracious rampage on Black bodies and minds, Black women have developed and evolved a tested blueprint for relationship-based coalition-building in support of progressive movements for social change.

The elements of this tested blueprint include, but are not limited to, the following: a clear articulation of a collective future for all coalition partners; an investment in an iterative learning process within the collective to understand and then situate the diverse origin stories of coalition partners; and an acknowledgment that the life of the coalition is paramount, eschewing interest convergence. The work of Black women in authoring a blueprint for supporting women's suffrage was instrumental to the ratification of the Nineteenth Amendment. Black women used the same blueprint to fuel a movement to recognize the unfinished business of the Fourteenth Amendment, which focused on voting rights for Black people that was equally instrumental in the passage of the 1965 Voting Rights Act. More recently, Black women used the blueprint again in a coordinated movement to register record numbers of voters who turned out for the November 2020 election. Black women's success with organizing and movement work offers a window into the refinement of relationship-based coalition-building that can be replicated for many other progressive social change movements.

Mary Eliza Church Terrell represents how to perfect a clear articulation of a collective future for women's rights, women's suffrage, and racial equality. Terrell embraced relationship-based coalition building as exemplified by her work and collectivism as a leader among leaders of Black women's clubs and eventually as the first President of the National Association of Colored Women (NACW),

324. See Mayeri, supra note 309, at 23 ("While Murray's vision of white-southern-female progressivism faltered in practice, her conviction that women of color would provide pivotal leadership for an American human-rights revolution found a lasting legacy. Social movements such as \#MeToo, the Movement for Black Lives, \#SayHerName, the sanctuary-cities and immigrant'-rights movements, revitalized voter-protection efforts, ongoing reproductive-justice activism, prison and foster-care abolitionism, criminal-justice reform, low-wage and domestic workers' organizing, to name a few, all continue this tradition."). 
advocating for equality on behalf of Black people and women on the organization's platform "Lifting as We Climb."325

"The African-American women's club movement came of age on the national scene when Jim Crow segregation became entrenched and disfranchisement of Black men spread throughout the South." ${ }^{326}$ With Terrell leading through dignified advocacy, Clubwomen asserted their special "brand of suffragism that prioritized racial justice." 327 Terrell's message remained clear that "voting rights for [B]lack women were inseparable from questions of [B]lack men's disfranchisement and the broader freedom struggle." ${ }^{328}$ Even with her intersectional lens finely focused on race and gender, Terrell never gave up on Susan B. Anthony and Alice Paul, continuously keeping the door to relationship-based coalitionbuilding open to them by answering white women's frequent calls to action and protest, although reciprocation by white women remained elusive, as they ignored Black women's protestations that the former should also lift as they climbed. ${ }^{329}$

325. See JONES, supra note 88, at 153-62 (describing the philosophy and the work of the NACW to recognize who had power and influence and what those resources should be used for: In part, Lifting as We Climb acknowledged inequalities among women and recognized that "some women [were] in need of help and others [were] in a position to provide it," and this philosophy extended to Marcy Church Terrell's and the organization's larger portfolio which included "combat[ting] lynching, secur[ing] civil rights, and ...work[ing] toward the vote ... while maintaining alliances with white women").

326. See id. at 152 ("[T] he very moment that Jim Crow's proponents purged Black men from much of public life, Black women were firming up their place in political culture [through collectivism in the Black women's club movement]."); see also Alison M. Parker, Mary Church Terrell: Black Suffragist and Civil Rights Activist, NATIONAL PARK SERVICE, https://www.nps.gov/articles/000/mary-church-terrell-blacksuffragist-and-civil-rights-activist.htm (last visited July 16, 2021).

327. See id. at 153-62; see also TERBORG-PENN, supra note 136, at 82 (1998).

328. See Jones, supra note 88, at 156 ("Terrell saw the problem of 'race' and 'sex' as intertwined, part of one great concern for humanity. She did not privilege the so-called rights of women over the rights of Black Americans.").

329. See id. at 154-55 (summarizing Terrell's sentiment that Black women's politics grew out of a history that they shared, in part, with white women); see also Parker, supra note 326. Terrell and her daughter frequently joined protests organized by Paul's National Woman's Party (NWP), and the former documented in her memoir how she 
A commitment to relationship-based collectivism with and among diverse coalition partners requires an investment in an iterative learning process within the collective to understand and then situate the diverse origin stories of the various coalition partners. This investment derides interest convergence and demands that coalition partners don the frames of reference of coalition members, especially those members at the fringes of the collective. This approach also requires awareness of one's ascension within a movement, especially at the expense of others often having intersectional identities farthest from the societal default. The iterative cycle, however, remains unbroken when the centering of the partners farthest from the societal default experience ascension within the coalition; that centered constituency then recenters the frame on the partners now farthest from the societal default who then experience ascension, and so on, and so on. This iterative process promotes a sphere of inclusiveness within relationship-based coalitions.

An example of such a sphere of inclusiveness is the Student Nonviolent Coordinating Committee's (SNCC) awakening of the activism and collectivism of Fannie Lou Hamer. Hamer existed at the fringes of Southern society governed stringently by legal and extra-legal measures instituted by white people that subordinated Black people-Jim Crow. ${ }^{330}$ White people dictated where Black people could live, what work they could do, how they had to behave, and exacted violence on them, whether or not Black people transgressed these rules enforcing white supremacy, domination, and subjugation. ${ }^{331}$ Upon learning about the right to vote after attending her first SNCC meeting, Hamer joined the interracial civil rights group with the intent to transform American society through the power of the ballot. ${ }^{332}$ Centering her story - as opposed to herself-SNCC provided a platform

answered Paul's calls to picket the White House even though Paul ignored Black women's demands for the NWP to work to secure voting rights for Black people.

330. See FRANKLIN \& HigGinBothaM, supra note 57 at 260-63.

331. See id.

332. See Fannie Lou Hamer, PBS, https://www.pbs.org/wgbh/americanexperience/features/freedomsummer-hamer/ (last visited Aug. 15, 2021) (chronicling the demand for Hamer as a speaker and fundraiser linking the authenticity of her story as captured in her testimony to the Credentials Committee, which "challenge[d] the seating of the all-white Mississippi delegates at the Democratic National Convention. Hamer was elected vice chair of the integrated delegation, which consisted of 64 black members and four white members"); see also Keisha N. Blain, Fannie Loue Hamer's Dauntless Fight for Black Americans' Right to Vote, SMITHSONIAN MAGAZINE, https://www.smithsonianmag.com/history/fannie- 
for Hamer to tell her story, one that was representative of the lived experiences of Black people in Mississippi. ${ }^{333}$ Hamer joined SNCC members in conducting voter registration workshops, laid her body on the line for SNCC initiatives, and spoke about her lived experience being terrorized, sexually assaulted, and traumatized at the hands of Southern white people, including state troopers. ${ }^{334}$ Undaunted, Hamer later ran for a U.S. House of Representatives seat in Mississippi, drawing support from ordinary people whom she joined forces with daring to demand, in the most public spaces, voting rights for all. ${ }^{335}$

During her ascension, Hamer helped to establish Mississippi Freedom Democratic Party (MFDP), among other things, to draw attention to "a "whitesonly' Democratic Party representing a state in which one out of five residents were [B]lack [, arguing that this] undermined the very notion of representative democracy. . . [and pointed out] that those who supported a 'whites-only' party were no different than white mobs who employed extralegal methods to block African Americans from voting." 336 Hamer centered the frame on the impoverished rural communities of the Mississippi Delta by establishing Freedom Farms, a communitybased rural and economic development project, and on women's political

lou-hamers-dauntless-fight-for-black-americans-right-vote-180975610/ (last visited Aug 15, 2021).

333. See Jones, supra note 88, at 257 (explaining that "Hamer spoke on behalf of the hundreds of thousands of Black Americans who, like her, were denied voting rights").

334. See id. at 258; see also Blain, supra note 332; DeNeen L. Brown, Civil Rights Crusader Fannie Lou Hamer Defied Men—and Presidents—Who Tried to Silence Her, WASH. PosT (Oct. 6, 2017), https://www.washingtonpost.com/news/retropolis/wp/2017/10/06/civil-rights-

crusader-fannie-lou-hamer-defied-men-and-presidents-who-tried-to-silence-her/; Lani Guinier \& Gerald Torres, Changing the Wind: Notes Toward a Demosprudence of Law and Social Movements, 123 YALE L.J. 2740, 2766-67 (2014).

335. See Blain, supra note 334; see also Guinier \& Torres, supra note 334 at 3761-62 (explaining the coalition "delegation ... was composed of ministers, farmers, sharecroppers, domestics, and the unemployed. [Delegates] spanned the Mississippi [B]lack community, and they demanded to be seated at the convention as official Mississippi delegates." Guinier and Torres state that "Hamer spoke to the nation on behalf of an organized and mobilized constituency that reimagined the structure of democratic representation" by contesting "the way in which representation was understood").

336. See Blain, supra note 332. 
participation by becoming a founding member of the National Women's Political Caucus, a multiracial "national organization dedicated exclusively to increasing women's participation in all areas of political and public life." 337 This collectivism manifested her goal of organizing for voting rights, not as an end to a movement, but as a prerequisite "to develop the power of the local people to change their own circumstances." 338 Hamer, educated through life's unfair lessons, was a sharecropper, an organizer, and a believer in the importance of the principles of the United States Constitution to "guarantee . . Black Americans voting rights." 339 She was, and remains, the bridge connecting the lived experiences of emancipated Black women during Reconstruction, the first and second-wave Black women who dedicated themselves to universal suffrage, and today's Black women practicing collectivism according to the universal suffrage blueprint handed down through the generations. $^{340}$

Black women have a store of knowledge and deep experience with service to community over self. Black women, collectively, engage with the notion that lived experiences inspire relationship-based coalitions, knowing that such coalitions are significantly more important than transactional coalitions, eschewing interest convergence. ${ }^{341}$ The advocacy and relationship-based approach to coalitionbuilding adopted by attorney Stacey Abrams is instructive of Black women's genealogy with universal suffrage.

Stacey Abrams, with many Black women partners, their allies, and the voters in Georgia, illustrated the central role of the collectivism of Black women in decisively bending the arc of justice toward universal suffrage. Citing the legacies

337. See NAT'L WoMEN's Pol. CAUCUS, Early History, https://www.nwpc.org/about/ (last visited July 16, 2021).

338. See Guinier \& Torres, supra note 334 at 2772 ("Hamer and the other delegates of the MFDP sought to expand the democratic potential in Mississippi and in Atlantic City by saying that the right to participate belonged to all, not just to those deemed qualified by elites, whether black or white. Merely securing the right to vote, or gaining access to a convention seat for two 'representatives,' was not the same as 'freedom.' 'By representing the poorest of Mississippi's residents, people without the "qualifications" that accompanied middle-class status, the MFDP repudiated traditional criteria of leadership."”).

339. Jones, supra note 88, at 257; see also Guinier \& Torres, supra note 334, at 2772.

340. See Broussard, supra note 27, at 665.

341. See Murphy, supra note 321, at 3. 
of Fannie Lou Hamer and her own grandmother, Stacey Abrams proclaims that she has drawn on them in the pursuit of the governorship in Georgia, the fight to have votes recounted in her gubernatorial bid, and the fight against voter suppression. ${ }^{342}$ She also points to the centuries of Black women's tradition of organizing for, among other rights, self-determination through access to the ballot as fuel for the fight for universal suffrage. ${ }^{343}$

An adherent to collectivism borne by years of coalition-building around voting rights, Abrams credits Black women such as Nsé Ufot, Helen Butler, Deborah Scott, LaTosha Brown, Britney Whaley, Amber Bell, Melanie Campbell, and Tamieka Atkins, with the success, among other grassroots organizers, in increasing turnout among Black voters by over 800,000 in the 2020 presidential election. ${ }^{344}$ Fair Fight, the nonprofit organization founded by Abrams, works to ensure that every American has a voice in the nation's election system; ${ }^{345}$ it cooperates with a network of organizers that includes:

- Georgia Stand-Up - A think-act tank that works on civic and voter engagement, transit, affordable housing, and other issues, mostly in communities of color.

- Working Families Party - A progressive political party that recruits, trains, and endorses candidates whose platforms include fair wages and criminal justice reform.

- Georgia Coalition for the People's Agenda - An organization with the mission of improving governance through civic participation, voter registration, and education.

- Black Voters Matter - A nationwide group established to build Black political power and the capacity of Black-led organizations by providing funding and coordination for get-out-the-vote efforts.

342. See Anna North, 6 Black Women Organizers on What Happened in Georgia-and What Comes Next, Vox (Nov. 11, 2020, 9:00 AM), https://www.vox.com/21556742/georgia-votes-election-organizers-stacey-abrams.

343. See StACEY ABrAMs, OUR TIME IS Now 3-4, 67-69 (2020); see also JONES, supra note 157 , at $274-75$.

344. See Olivia B. Waxman, Stacey Abrams and Other Georgia Organizers Are Part of a Long-But Often Overlooked-Tradition of Black Women Working for the Vote, TIME (Jan. 8, 2021, 10:00 AM), https://time.com/5909556/stacey-abrams-history-blackwomen-voting/; see also North, supra note 342.

345. See FAIR FIGHT, Meet Our Founder, https://fairfight.com/about-stacey-abrams/ (last visited Aug. 15, 2021). 
- Southwest Georgia Project for Community Education - An organization dedicated to food security, issues facing family farmers, and civic engagement in rural southwest Georgia.

- The National Coalition on Black Participation - A group helping citizens vote with minimum barriers.

- ProGeorgia - A statewide coalition helping grassroots groups register voters and organize around relationship-building to maximize voter and civic engagement. ${ }^{346}$

Abrams's focus on the voters and on the partners in her network draws from the blueprint of Black women's advocacy and relationship-based coalition work from prior generations in service to universal suffrage. Her commitment to accountability to voters and voting coalitions is evident, for example, in her decision not to challenge the math of her historic bid and slim loss to become Governor of the State of Georgia in 2018, but deciding to instead challenge voter suppression in the aftermath. ${ }^{347}$ Similar to Black women suffragists who chose to turn their coalition work into the fight against Jim Crow segregation after being disfranchised in the period following the ratification of the Nineteenth Amendment, Abrams turned her leadership skill and energy to creating a "new organization [,] [Fair Fight,] with a mission to guarantee better elections" for voters and for those candidates who followed her. ${ }^{348}$

\section{CONCLUSION}

There are several purposes for writing this work, especially in the medium of law review literature. First and most critical, this article centers Black women's voices and lived experiences in shaping law, citizenship, social movements, coalition-building, and the democratic ideal of equality. Second, this article introduces to some and reintroduces to others the impact of Black women as abolitionists, women's suffragists, and as drivers of the universal suffrage and humanist movements. Third, this article connects Black women's relationship-based

346. See North, supra note 342; see also Erin Feher, Meet the Black Women Who Turned Georgia Blue, https://representcollaborative.com/stories/meet-the-black-women-whoflipped-georgia (last visited Aug. 15, 2021).

347. See Stacey Abrams, Lead From the Outside: How to Build Your Future and MAKE REAL CHANGE, at xiii (2019).

348. See id. at xvii. 
coalition-building and perpetual struggle for universal suffrage to the successes of expanding the franchise for all.

As American democracy is struggling mightily with crucible events that threaten its democratic institutions and the rule of law-made unquestionably apparent by the January 6,2021, insurrection and its hyper-partisan aftermaththere is no more perfect time to recognize and adopt the blueprint developed by Black women. This blueprint passes like a baton from generation to generation, being honed for every era to respond to the strengths, weaknesses, challenges, and opportunities of American democracy. Black women have consistently proven that their collective organizing, coalition-building, abolitionism, and contestation have been rooted in universal humanism, the support of their communities, and in the striving to expand the power and promise of the democratic ideal of equality for all. The blueprint to rebuild American democracy has been and continues to be written by Black women who have proven over and over again their willingness and their resolve to be in relationship-based coalitions with a diversity of partners. 